\title{
Pakistan and the War on Terror
}

GONFLIGTED GOALS, GOMPROMISED PERFORMANGE

\section{Ashley J. Tellis}




\title{
Pakistan and the War on Terror
}

\section{C onflicted G oals, C ompromised Performance}

\author{
Ashley J. Tellis
}

CARNEGIE ENDOWMENT

FOR INTERNATIONAL PEACE

WASHINGTON DC - MOSCOW - BEIJING - BEIRUT - BRUSSELS 
(c) 2008 C arnegie Endowment for International Peace. All rights reserved.

No part of this publication may be reproduced or transmitted in any form or by any means without permission in writing from the $\mathrm{C}$ arnegie Endowment.

The $\mathrm{C}$ arnegie Endowment normally does not take institutional positions on public policy issues; the views represented here do not necessarily reflect the views of the Endowment, its staff, or its trustees.

For el ectronic copies of this report, visit www.C arnegieE ndowment.org/pubs. Limited print copies are al so available.

To request a copy, send an e-mail to pubs@C arnegieE ndowment.org.

C arnegie Endowment for International Peace

1779 M assachusetts Avenue, N W

Washington, DC 20036

Phone: $202-483-7600$

Fax: 202-483-1840

www.C arnegieE ndowment.org

\section{ABOUT THE AUTHOR}

Ashley J. Tellis is a senior associate at the $C$ arnegie E ndowment for International Peace, specializing in international security, defense, and Asian strategic issues. He was recently on assignment to the U.S. D epartment of State as senior advisor to the undersecretary of state for political affairs. Previously he was commissioned into the Foreign Service and served as senior advisor to the Ambassador at the U.S. E mbassy in N ew D elhi and served on the $\mathrm{N}$ ational Security C ouncil staff as special assistant to the President and senior director for strategic planning and southwest Asia. Prior to his government service, Tellis was senior policy analyst at the RAND Corporation and professor of policy analysis at the RAND G raduate School. He is the author of India's E merging N ucl ear Posture (2001), and co-author of I nterpreting C hina's $G$ rand Strategy: Past, Present, and F uture (2000). He is the Research Director of the Strategic Asia program at NBR and co-editor of Strategic Asia 2007-08: D omestic Political C hange and G rand Strategy.

The author thanks Alyssa Ayres, Chris Fair, Jack G ill, Frédéric Grare, N eil Joeck, Dan M arkey, Jessica $M$ athews, and George Perkovich for their most helpful comments on the manuscript. Thanks are also owed to Sam M cC ormally for research assistance and to Riccardo Redaelli, M aria Sultan, the Indian, Pakistani, and E uropean participants at the L andau N etwork-C entro Volta workshops on South Asian security, the Afghan and Pakistani military officers at the annual confidence-building meetings in G armischPartenkirchen, G ermany, and to several Indian, Pakistani, and NATO diplomats and military officers for their insights into the challenges associated with counterterrorism operations in Operation Enduring Freedom. 


\section{C ontents}

Introduction $\quad 1$

Understanding Pakistan's Approach to the War on Terror 3

Explaining Pakistan's C ounterterrorism Performance 16

What C an the U nited States D o? 38

Notes $\quad 48$ 


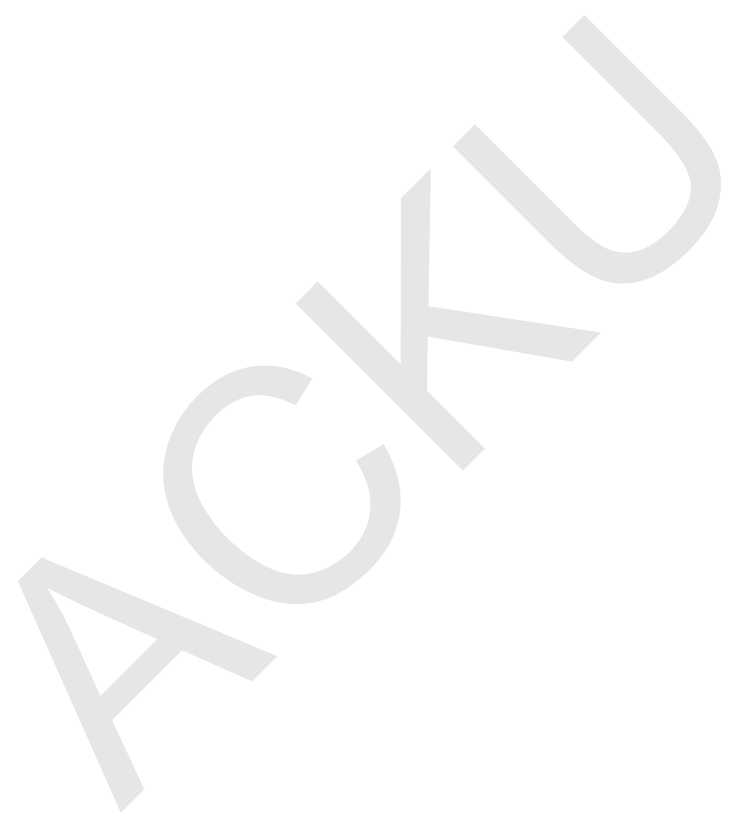




\section{Introduction}

On June 24, 2003, at a C amp D avid meeting with his Pakistani guest, President G eorge W. Bush declared that key al-Q aeda terrorists had been successfully neutralized thanks "to the effective border security measures and law enforcement cooperation throughout [Pakistan], and ... to the leadership of President Pervez M usharraf." Although O sama bin L aden was still at large, Bush nevertheless concluded that "the people reporting to him, the chief operators [of al-Q aeda], ... people like Khalid Sheik M ohammed, are no longer a threat to the U nited States or [to] Pakistan, for that matter."1

Barely four years later, the Bush administration has been compelled to revise the president's earlier, more optimistic, assessment. Faced with a dramatic resurgence of the Taliban in Afghanistan and a steady reconstitution of the al-Q aeda network in the Federally Administered Tribal Areas (FATA) of Pakistan, the July 2007 N ational Intelligence Estimate, "T he Terrorist Threat to the U.S. H omeland," asserted forthrightly that al-Q aeda "has protected or regenerated key elements of its homeland attack capability, including: a safe haven in the Pakistan Federally Administered Tribal Areas (FATA), operational lieutenants, and its top leadership."2

That the rejuvenation of al-Q aeda and the Taliban is due in large part to their ability to secure a sanctuary in Pakistan has incensed many Americans across the political spectrum. Because Washington has provided Islamabad with almost $\$ 10$ billion in overt security and economic assistance since 2002 and continues to compensate the Pakistani military for its counterterrorism efforts with roughly $\$ 1$ billion in annual reimbursements, many U.S. leaders are beginning to wonder whether Pakistan is in fact doing its part in the war on terror. ${ }^{3}$ The U.S. Congress, signaling its disenchantment with Islamabad's counterterrorism effectiveness (and with M usharraf's recent backsliding on democracy), has sought to condition U.S. aid to Pakistan and has withheld some military assistance funding in an effort to prod more aggressive Pakistani military operations against al-Q aeda and the Taliban. Two D emocratic presidential candidates, Barack O bama and John E dwards, have gone even further, declaring that U.S. military forces operating in Afghanistan and elsewhere ought to be employed unilaterally against terrorist targets in Pakistani territory if I slamabad fails to interdict them despite possessing actionable intelligence. ${ }^{4}$

The growing dissatisfaction in the U nited States about Pakistani performance in counterterrorism operations is premised largely on the assumption of I slamabad's mendacity: that M usharraf's regime, despite being well compensated and despite its habitual claims to be performing at par, is willfully neglectful of its commitment to root out al-Q aeda and Taliban cadres operating from its territory for a combination of strategic and ideological reasons. ${ }^{5}$ The reality, however, is more complex. Although Pakistani performance in the war on terror has undoubtedly fallen short of what is expected in the U nited States, Islamabad's inability to defeat the terrorist groups operating from its soil is rooted in many factors going beyond its admittedly serious motivational deficiencies in regard to combating terrorism. 
This monograph seeks to provide an analytical understanding of the problems associated with Pakistani performance in the combined counterterrorism operations currently under way in the FATA and in Afghanistan. Such an understanding is essential if the U nited Statesis to avoid becoming locked into the paralyzing choices of either coercing Pakistan-with varying degrees of discrimination - as urged by many voices in the current political debate or standing steadfast through publicly uncritical support for M usharraf as the Bush administration has done so far. The discussion that follows underscores the fact that, although Pakistan is a conflicted ally in the war on terror, it faces difficult counterterrorism challenges that cannot be overcome quickly for good reasons. The campaign against al-Q aeda and the Taliban, accordingly, will be a long one requiring considerable patience on the part of the U nited States. Further, the analysis suggests that there are no easy choices for Washington, but it also emphasizes that I slamabad's approach to defeating terrorism is sufficiently risky and could end up transforming Pakistan into an object of U.S. wrath should a major attack on the U nited States in the future reveal Pakistani origins, neglect, or, in the worst case, connivance. 


\section{Understanding Pakistan's Approach to the War on Terror}

Although Pakistan has been a frontline state in the war on terror since the tragic events of September 11, 2001, there is no doubt that G eneral M usharraf initially cast hislot with the U nited States mainly as a result of deep fears about what U.S. enmity might imply for Pakistan'slongstanding rival ry with India, its efforts at economic revival, its nuclear weapons program, and its equities in the conflict over Kashmir. ${ }^{6}$ D esi rous of protecting Islamabad's interests in these areas and to avoid Pakistan becoming a target in the campaign against terrorism, M usharraf reluctantly cut loose Islamabad's ties with the Taliban- a force it had nurtured, trained, and equipped for al most a decade in its effort to secure control over Afghanistan- and stood aside as the U.S.-led coalition assisted its detested antagonist, the N orthern Alliance, to rout its own clients and their al-Q aeda accomplices and seize power in Kabul. Because the al-Q aeda elements in Afghanistan during the 1990s were never directly dependent on the Pakistani InterServices I ntelligence Directorate (ISID) for their success (despite maintaining a significant liaison relationship), the ejection of their Arab, African, and C entral Asian mercenaries was viewed with fewer misgivings than the flight of the Pashtun-dominated Taliban, who were tied to Pakistan directly in terms of both patronage and ethnicity. ${ }^{7}$

Islamabad'sties to the Taliban were so strong and so important that throughout the initial phase of Operation Enduring Freedom, General M usharraf and his cohort implored the U nited States to desist from decisively destroying M ullah M uhammad O mar's regime in Afghanistan. When this objective could not be secured, Pakistani leaders argued against all coalition military operations that would result in ejecting the Taliban's foot soldiersfrom their traditional bases in the southeastern provinces of the country. When these entreaties were al so disregarded by the United States and the comprehensive defeat of the Taliban appeared inevitable as a result of joint U.S. and N orthern Alliance military operations, Islamabad responded by covertly exfiltrating its army and intelligence personnel seconded to the movement-along with some key Taliban operatives, if Indian intelligence sources are accurate- while permitting the defeated stragglers to cross over to safety across the frontier and into Pakistani territory. ${ }^{8}$ Taliban forces and their al-Q aeda guests thus found their way across the highly porous Afghanistan-Pakistan border into the FATA. W hile Pakistani border patrols concentrated their efforts against the latter group, resulting in the seizure of numerous low-level al-Q aeda elements, these operations nonethel ess were never rigorous or watertight enough and were, in any event, frustrated by other factors: the old tribal tradition of extending succor to strangers who ask for protection; the region's history of providing foot soldiers, first, for the anti-Soviet jihad and, later, for the war against the N orthern Alliance in Afghanistan; the absence of a strong Pakistani state presence in this area; and the utterly hostile topography consisting of remote and difficult mountain terrain with poor lines of communication, all of which combined to bestow on the defeated remnants a substantial measure of sanctuary and assistance. ${ }^{9}$ 
The U.S. inauguration of the "global war on terror" soon compelled General M usharraf to make good on his "principled" decision to join the U.S.-led coalition. This inevitably required $\mathrm{M}$ usharraf to confront the sources of terrorism that had developed internally in Pakistan, most of which ironically resulted from his own army's previous decisions to nurture radical Islamist organizations because of their utility to Islamabad's military campaigns in Kashmir and Afghanistan. ${ }^{10}$

Four different terrorist groupings were implicated in this regard. The first were the domestic sectarian groups like the Sunni Sipah-e-Sahaba and its offshoot the L ashkar-e-J hangvi and the Shia Tehrik-e-Jafria Pakistan and its offshoot the Sipah-e-M uhammad, which were engaged in violent bouts of bloodletting within the country. Although many of these groups had enjoyed the support of the Pakistani government, the military, and the intelligence services previously, their unexpected growth in power over time had become not only an embarrassment to their sponsors but al so a serious challenge to domestic order. ${ }^{11}$ As C hristine Fair has summarized it, "The scale of sectarian violence in Pakistan is staggering, with hundreds of people killed or injured in such attacks each year."12 The N ew D elhi-based Institute for C onflict M anagement has documented sectarian violence al one as claiming close to 5,000 lives in Pakistan since 1989, with incidents involving everything from targeted killings of highprofile civilians, to bombings of mosques and drive-by shootings of innocents, to pitched gun battles in major population centers. In one incident, for example, sectarian hostility in the town of Parachinar in the Kurram Agency involved a five-day war, where small arms, mortars, rocket launchers, and antiaircraft missiles were all used in a convulsive spasm that claimed hundreds of lives and injured many more. ${ }^{13}$

C onfronted by such challenges to the writ of his state, M usharraf was only too happy to exploit the opportunities offered by the war on terror to crack down on these groups and suppress them once and for all. He did so, however, only selectively. Focusing the government's energies primarily on those D eobandi and Shia groups whose objectives were out of sync with the military's perception of the national interest, he targeted Sunni groups such as the Lashkar-e-J hangvi, the Sipah-e-Sahaba Pakistan, the Harkat-ul-M ujahideen al-Alami, the Jundullah, and to a much lesser degree the H arkat-ul-jihad-e-l slami, as well as Shia threats such as the Sipah-e-M uhammad, primarily because they were engaged in "anti-national" jihadi violence within Pakistan rather than in support of Islamabad's external ambitions visà-vis India and Afghanistan. U sing the entire panoply of coercive state capabilities, these entities were therefore put down with a heavy hand through arrests, targeted assassinations, and aggravated intergroup massacres. Although many of the toolsused to defeat these perpetrators of sectarian violence were often unconstitutional, $M$ usharraf shrewdly judged that the aggressive dismemberment of these groups would not evoke either domestic or international condemnation. He was right.

U sing the opportunities therefore afforded by the global war on terror, the Pakistani security services systematically eliminated many sources of sectarian violence within two years of the campaign's initiation, even though they have been unable to conclusively eradicate the cancer of sectarian bloodshed within Pakistan itself. ${ }^{14}$ In part, this is due to the selectivity of 
M usharraf's antisectarian campaign. But the continuing fragmentation of these violent groups; their links to the wider networks of international terrorism now resident in Pakistan, various foreign sponsors abroad, and the flourishing madaris within the country; and the continuing utility of their gun-toting membership to different political parties and occasionally to governmental organs themselves imply that sectarian threats will be impossible to extinguish so long as "state policies of I slamisation and [the] marginalization of secular democratic forces" continue to persist in Pakistan. ${ }^{15}$

The second set of groups, the terrorist outfits operating with Pakistan Army and ISID support against India in Kashmir, was treated in a remarkably different way compared with the anti-national sectarian militants inside Pakistan. These groups, such as the Lashkar-e-Toiba, the Jaish-e-M uhammad, and the H arkat-ul-M ujahideen, for example, were the long lances in the Pakistani campaign to wrest the disputed state of Jammu and Kashmir from India. Since the late 1980s, the Pakistani military has financed, trained, armed, and launched these cadres on their murderous missions into Kashmir and elsewhere inside the Indian union. Because the struggle for control over the disputed $\mathrm{H}$ imalayan state was fully under way by the time the global war on terror was inaugurated, these terrorist groups were more or less exempted from M usharraf's domestic campaign against violence and extremism.

This exclusion was justified both on the strategic rationale that Pakistan's participation in the war on terror was intended, among other things, to protect its freedom of action in Kashmir and on the repeated, though fraudulent, assertion that these groups, far from being terrorists, only personified the legitimate Kashmiri struggle for self-determination against India. ${ }^{16}$ In fact, of all the Pakistani-sponsored D eobandi terrorist groups operating against India in Kashmir and elsewhere, only one entity - the Hizbul M ujahideen - began life as an indigenous Kashmiri insurgent group; the others, including the most violent organizations such as the Lashkar-e-Toiba, the Jaish-e-M uhammad, and the Harkat-ul-M ujahideen, are all led, manned, and financed by native Pakistanis. ${ }^{17} \mathrm{~T}$ his real ity notwithstanding - and perhaps because of it-I slamabad continued to sustain the operations of these groups against India but, in an effort to maintain the consistency of its commitments to the global war on terror, now began to emphasize that its support took only the form of moral, and not material, encouragement.

This charade was rudely interrupted by the D ecember 13, 2001, terrorist attack on India's parliament when, in response to N ew D elhi's subsequent military mobilization, Pakistan was compelled by U.S. diplomacy to initiate a series of measures to restrict the activities of its terrorist clients. The implementation of these actions, however, was at best halfhearted and inconsistent. Far from seeking to extirpate these terrorist groups permanently, M usharraf sought mainly to defang India's threats of military action and to all leviate Washington's fears of an inconvenient Indo-Pakistani war. His overarching objective consisted of protecting these terrorist assets to the extent possible because they represented national investmentsa "strategic reserve"18_-in Islamabad's subconventional war against $\mathrm{N}$ ew D elhi. Consequently, to this day, M usharraf has not sought to eliminate the Deobandi terrorist groups operating against India in Kashmir and elsewhere; he has instead sought only to modulate 
their activities, depending on the extent of satisfaction he derives from the prevailing state of diplomatic relations with $\mathrm{N} \mathrm{ew}$ D elhi and the progress secured in the ongoing Indo-Pakistani peace process.

Although the Pakistani-supported infiltration of terrorist groups into Kashmir- but not into the rest of India - appears to have abated in recent years, most observers conclude that this phenomenon is linked either to M usharraf's desire not to provide India with any excuses to abandon the generally fragile peace process or to domestic crises within Pakistan. In any event, it is agreed that $\mathrm{M}$ usharraf simply has not made the decisive decision to abandon or eliminate the terrorist groups operating against India in the manner witnessed, for example, in the case of the more virulent anti-national sectarian entities operating within Pakistan.19

The third group relevant to the Pakistani decision to join the U.S.-led coalition against terrorism consisted of the Taliban, that is, the Pashtun remnants of the regime ejected from power in Kabul as a result of the initial success of $\mathrm{O}$ peration Enduring Freedom. After their defeat at the hands of the N orthern Alliance, the Taliban cadres hastily returned to the regions whence they originated. $M$ any in the rank and file withdrew to their villages in the southern Afghan provinces of $\mathrm{H} \mathrm{elmand,} \mathrm{Kandahar,} \mathrm{O} \mathrm{ruzgan,} \mathrm{and} \mathrm{Zabol} \mathrm{as} \mathrm{well} \mathrm{as} \mathrm{along} \mathrm{the}$ border areas on the western side of the D urand Line separating Afghanistan from Pakistan, that is, in the eastern Afghan provinces of Paktika, Paktia, Khowst, $N$ angarhar, and Konar. Given their significance as high-value targets, the core Taliban leadership-along with those Pakistani Pashtuns who had joined their movement-crossed over the AfghanistanPakistan border into the relative safety of the FATA. Because most of the Taliban's fighters originally mobilized by the Pakistani ISID were drawn from the Ghilzai confederation of Pashtuns, which dominates eastern and southeastern Afghanistan, and from the other Pashtun tribes inhabiting the FATA, their return to these ancestral lands was not surprising. In fact, all the evidence relating to the incidence of terrorist attacks since 2001 suggests strongly that the war-fighting cadres of the Taliban continue to remain bivouacked in these areas (see figure 1).20

The exact location of the supreme leadership of the Taliban movement, however, cannot be established with any self-evident clarity. Irrespective of where the rahbari shura (leadership council) centered on M ullah O mar and his closest associates found shelter in the immediate aftermath of their defeat, Afghan military and civilian intelligence officials as well as N ATO commanders today believe that this coterie eventually found refuge in Quetta, the largest city and capital of Pakistan's Baluchistan Province, from where they continue to operate to this day. As Col. C hris Vernon, N AT O 'schief of staff for southern Afghanistan, declared forthrightly, "The thinking piece of the Taliban [operates] out of Q uetta in Pakistan. It's the major headquarters - they use it to run a series of networks in Afghanistan."21 These networks, in turn, are judged to be directed by four subsidiary shuras based in Quetta, M iran Shah, Peshawar, and Karachi: the first three actually control or coordinate most of the ongoing terrorist operations occurring, respectively, al ong the southern, central, and northern "fronts" in Afghanistan (see figure 2), whereas the fourth is believed to connect the Taliban with the logistics, financial, and technical assistance conduits emanating from the wider Islamic 


\section{Figure 1. Terrorist Attacks in the Provinces of Afghanistan, January 2002- mid-April 2007}

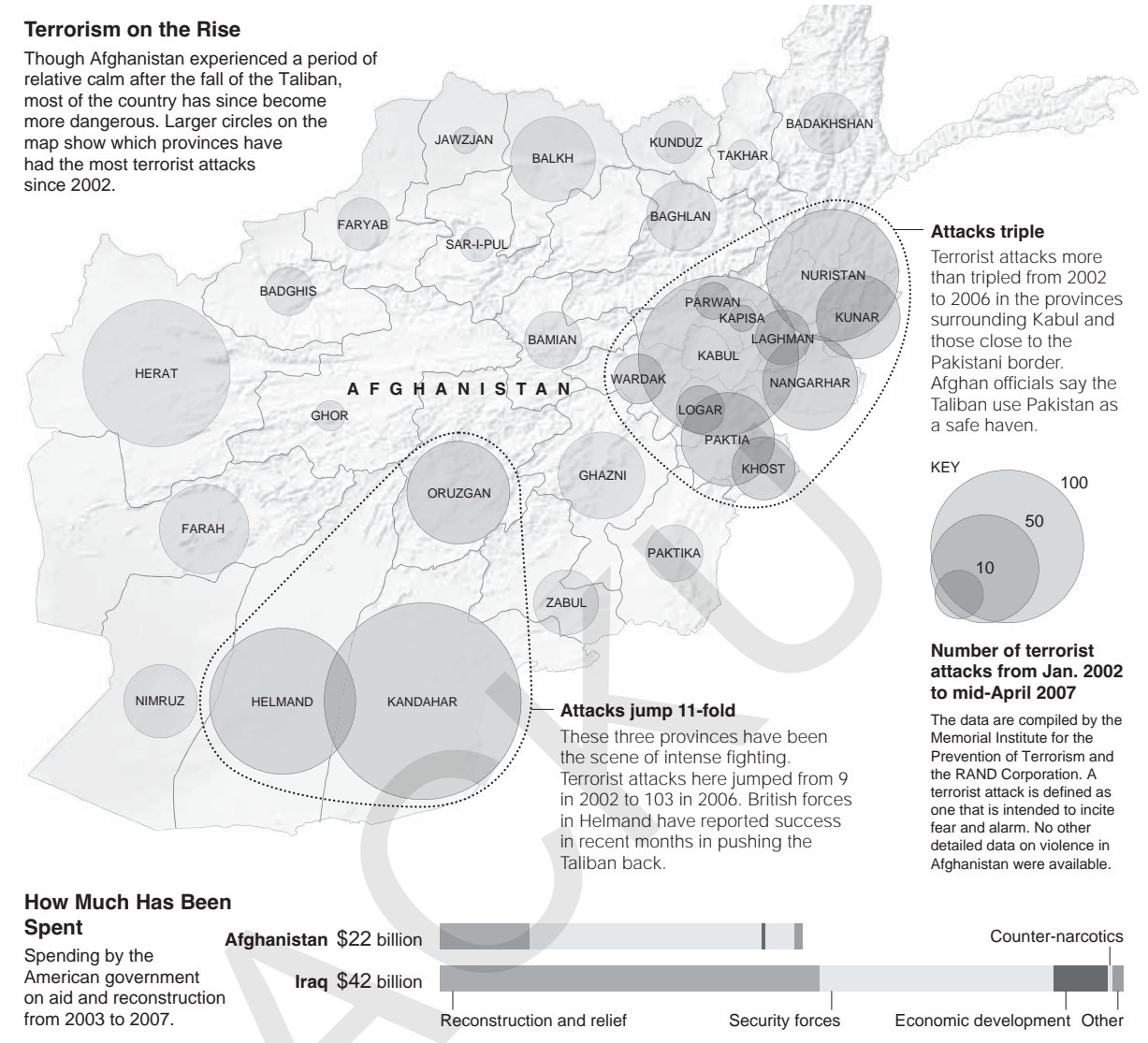

Source: N ew York Times G raphics.

world.22 The pattern of terrorist attacks occurring in Afghanistan from 2002 to 2007, illustrated in figure 1, again corroborates this judgment.

Because the Pakistani state was most intimately involved in the creation of the Taliban before their fall, M usharraf's antiterrorism campaign after September 11, 2001, deliberately avoided any concerted targeting of this group and, in particular, its senior leadership. ${ }^{23} \mathrm{No}$ other explanation is consistent with the fact that, although Pakistani military, intelligence, and paramilitary forces apprehended scores of al-Q aeda operatives, including numerous key individuals in the al-Q aeda hierarchy, the senior Taliban leaders killed or captured in southern Afghanistan or in the FATA have numbered literally a handful in comparison. This asymmetry in seizures is all the more odd because, prior to O peration E nduring Freedom, Pakistani military and ISID liaison el ements were deeply intertwined with all levels of the Tal iban com- 


\section{Figure 2. Location of the Three M ajor Fighting Fronts in Afghanistan}

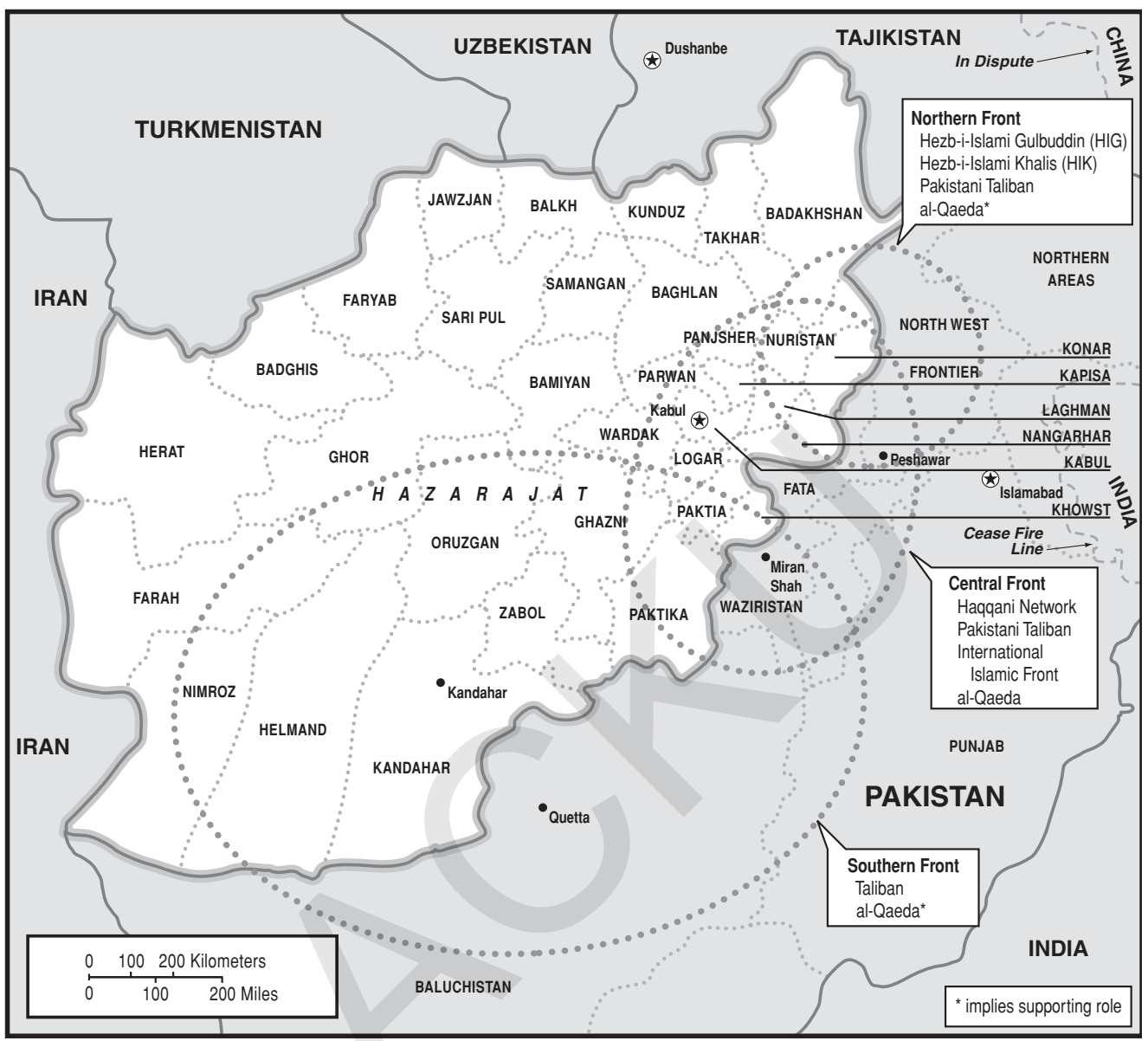

Source: Seth G . Jones, “Pakistan's D angerous G ame," Survival, 49:1 (2007), p. 20.

mand structure and its war fighters in the field. In contrast, the Pakistani intelligence relationship with al-Q aeda in Afghanistan was more tenuous, yet Pakistan's military forces were able to apprehend far more al-Q aeda cadres than Tal iban operatives. These successes in regard to al-Q aeda have invariably been attributed by Pakistanis, including $\mathrm{G}$ eneral M usharraf, to the fact that it was always easier to identify the ethnically alien al-Q aeda elements along the frontier in comparison with the Taliban who, being ethnically Pashtun, were able to disguise their identities by assimilating into the larger tribal population. ${ }^{24}$

While this explanation is only partly true- non-native fighters have lived in and become amal gamated into the social structures of the Afghan-Pakistani frontier since at least the antiSoviet jihad of the 1980s-it is also disingenuous because the Pakistani ISID was not only 
deeply involved in the recruitment, training, arming, and operations of Taliban fighters at multiple bureaucratic levels, but it also maintained an intense liaison relationship with the Ghilzai tribes whose population has been disproportionately represented in the Taliban. Since protecting these relationships was deemed to be especially critical for Pakistan's national security interests in the aftermath of the N orthern Alliance victory in Kabul, the large number of Taliban foot soldiers who made their way into the FATA were largely ignored by Pakistani counterterrorism operations so long as they did not engage in any untoward activities that either called attention to their presence or magnified the troubles confronting the Pakistani state. All told, then, the Taliban network, just like the Pakistani-aided terrorist groups operating in Kashmir and elsewhere in India, was deli iberately permitted to escape the wrath of G eneral M usharraf's counterterrorism operations in the initial phase of the war on terror. 25

Such an approach, however, could not be extended to the fourth group, al-Q aeda, which had al so taken up sanctuary in the FATA, particularly in South Waziristan initially. Although al-Q aeda continued to have sympathizers within the extreme fringes of Pakistani society even after the terrible events of September 11 were conclusively attributed to its operations, the Pakistani military establishment did not enjoy the luxury of slackening its campaign against this target because of the consequences for U.S.-Pakistani relations at a time when bilateral ties were just recovering after a decade of U.S. disfavor and when Washington had just embarked on a ferocious campaign against al-Q aeda worldwide. M ost senior Pakistani military officers at the corps command level were al so genuinely horrified by the destruction that al-Q aeda wreaked in N ew York and Washington and, fearing for their country's own future in the face of the monster now present in their midst, supported M usharraf's decision to engage and destroy this terrorist organization of global reach.

Pakistan's military, accordingly, began to prosecute the war against al-Q aeda with great vigor, if not al ways with finesse, through multiple instruments. ${ }^{26}$ These included providing the $U$ nited States and its military with facilities and access for the prosecution of O peration Enduring Freedom in Afghanistan, and conducting various law enforcement and internal security operations (sometimes in cooperation with their U.S. counterparts) aimed at interdicting terrorist financing and apprehending and rendering terrorist targets for prosecution abroad. M ost important, however, the Pakistani military initiated Operation Al M izan, a large-scale effort that involved moving major military formations from the Army's XI Corps and elite Special Services G roup (SSG ) battalions into the FATA, an area where regular army units had not ordinarily been deployed for decades. These infantry forcesjoined the Frontier Corps regiments- the paramilitary formations usually located in the region-as a show of force in order to both reassert the strong state presence that historically was lacking and apprehend the al-Q aeda elements that had taken shelter within the area. ${ }^{27}$

This military campaign, which took the form of a gigantic cordon-and-search operation, had several consequences. First, it resulted in the capture of numerous al-Q aeda and other extremist operatives - some 700 at last count - who have since been turned over to the U nited States. Because these individuals are mostly foreigners- non-South Asian arrivals living in 
what are essentially Pashtun lands- detecting their presence, while not easy because of the local support they receive from the natives for ideological reasons and sometimes simply out of greed or fear, was certainly easier.

Second, it forced some though by no means all senior al-Q aeda operatives- for example, Khalid Sheikh M uhammad and Ramzi Binalshibh - to leave the relatively secure FATA sanctuary and disperse further inward into Pakistan, where their insertion into less ideologically congenial surroundings and their need to rely on more complex means of communication increased their susceptibility to detection and arrest.

Third, the dramatic irruption of the Pakistani state into the FATA, through a significant military presence of the kind not seen in more than a century, resulted in making conditions sufficiently inhospitable for al-Q aeda such that its senior leadership and cadres were compelled to relocate under fire from South to $\mathrm{N}$ orth Waziristan and beyond, where they operate to this day (see figure 3). This forced displacement, which unfortunately remains at continuous risk of reversal, nonetheless had the beneficial effect of disrupting many planned terrorist operations, but the dispersal of the organization's leadership in the northern FATA, especially in the Bajaur Agency where the terrain is inhospitable, the population is violently pro-Taliban, and the presence of the Pakistan Army is thin, has inadvertently made the task of destroying the al-Q aeda core all the more difficult. 28

In any event, these outcomes suggest that al though Pakistan began as a reluctant entrant into the global war on terrorism, it has since become an active participant in the struggle. M ore than 85,000 Pakistani troops remain garrisoned along the Afghanistan-Pakistan border-a deployment that predates the initiation of the global war on terror. A significant fraction of these forces, however, is engaged today in counterterrorism operations in the border areas, and more than 600 soldiers have al ready sacrificed their lives in this effort. F urther, Islamabad itself has now become a victim of terrorism as a variety of groups, ranging from those previously nurtured and now discarded by the Pakistani state, such as the al-Alami faction of the $\mathrm{H}$ arkat-ul-M ujahideen, to more distant beneficiaries of past Pakistani policies, such as al-Q aeda, seek to wreak an orgy of revenge against institutions and individuals whom they had previously counted among their sponsors and friends.

That Pakistan has made significant contributions to defeating various terrorist groups is therefore undeniable, yet its larger campaign against terrorism has al so been conspicuously selective and perhaps self-serving. While it has secured major gains in eradicating some domestic anti-national sectarian terrorist groups and has contributed disproportionately to the ongoing campaign against al-Q aeda, it has been much more reluctant to conclusively eliminate those terrorist entities operating against India in Kashmir and elsewhere and against Afghanistan both in the FATA and in transit back and forth to the southern and eastern Afghan provinces. ${ }^{29} \mathrm{~F}$ urther, the protection of the terrorist infrastructure that supports these groups has produced undesirable blowback because the actors traditionally involved in perpetrating terrorism in Kashmir increasingly either coordinate with or directly assist the Taliban and al-Q aeda in operations against not only Afghanistan but al so the U nited States and even Pakistan itself. 30 
Figure 3. Federally Administered Tribal Areas

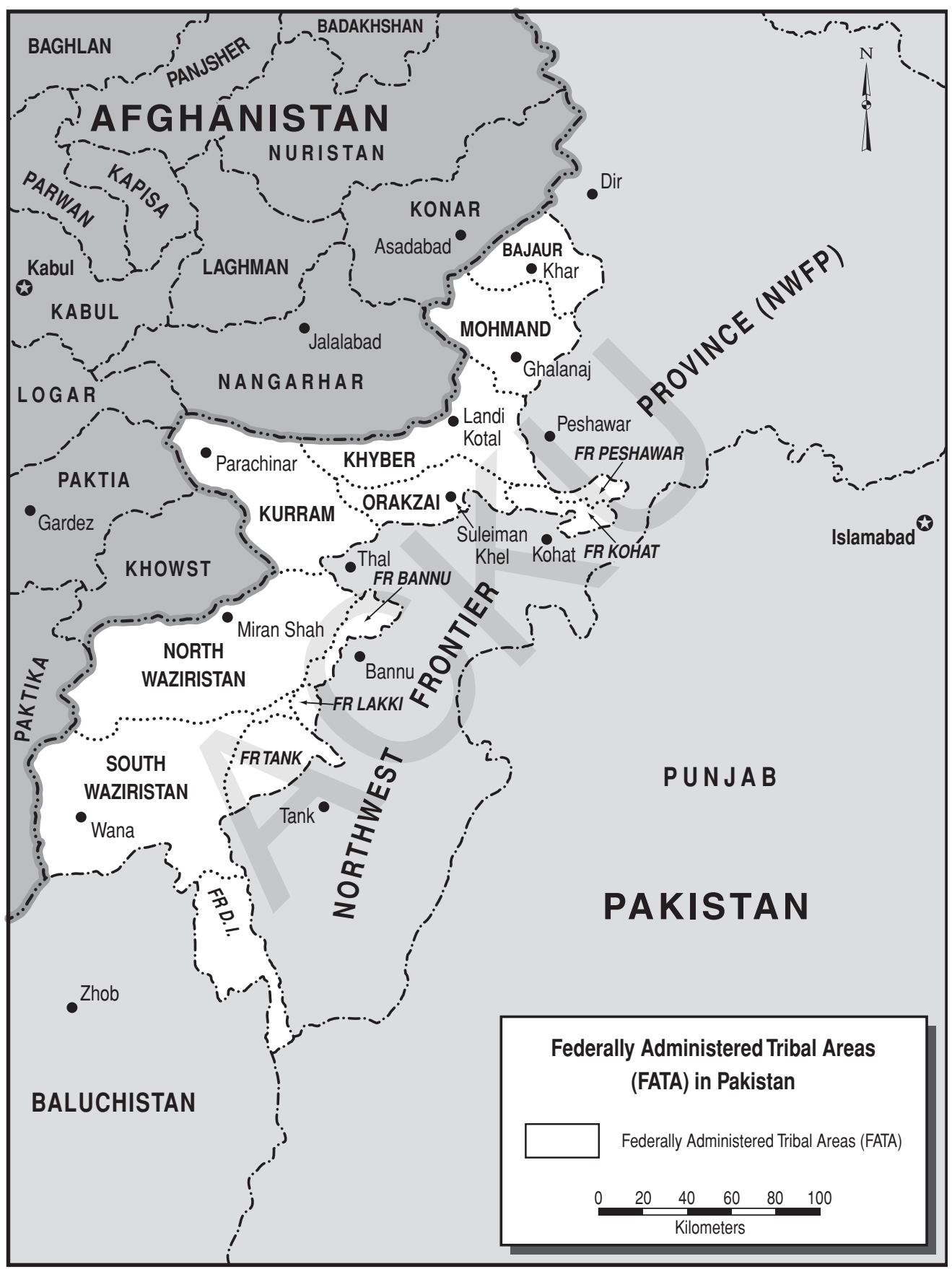


C learly, strategic and geopolitical cal culations play an important part in accounting for this segmented Pakistani response. I slamabad, for example, has long viewed the terrorist groups operating in Kashmir and now in other Indian states as useful instruments for executing its policy of "strategic diversion" against N ew D elhi.31 For this reason, Pakistan has been reluctant to target and eliminate these groups conclusi vely, preferring instead to al ternately tighten and loosen control over their operations depending on how much satisfaction it receives from India at any given moment. 32

The decision to avoid targeting the Taliban was born of similar calculations. I nitially, it was owed simply to the inclinations of senior Pakistani military commanders who were just not prepared to add insult to injury by physically eliminating the very forces they had long invested in, especially because they had now suffered the ignominy of having to consent to their client's defeat. O ver time, however, the reasons for protecting the Taliban only grew stronger: India's growing prominence in Afghan reconstruction, its increased influence and presence in Afghanistan more generally, the weakening of the Hamid Karzai government in Kabul, the progressive souring of Pakistani-Afghan relations (including those between Karzai and M usharraf personally), and the disquiet about a possible U.S. exit from Afghanistan (a prospect inferred from the mid-2005 announcement that the U nited States would divest full command of Afghan combat operations to NATO ) once again increased Pakistan's paranoia about the prospect of a hostile western frontier. It was exactly the desire to avert this outcome that led to the initial Pakistani decision to invest in sustaining the Taliban. And with fear of the wheel turning full circle gaining strength in I slamabad since at least 2005, the temptation to hedge against potentially unfavorable outcomes in Kabul-by protecting the Taliban as some sort of a "force-in-being" - only appeared more and more attractive and reasonable to Pakistan. 33

Although Pakistan's discriminative approach to fighting terrorism was shaped and implemented by $G$ eneral M usharraf in his dual capacity as president and previously chief of army staff, it would be erroneous to conclude that this prevailing strategy is owed simply to the whim of one man. This is particularly relevant today when M usharraf's hold on power has become progressively weaker and the future of his political status and effectiveness increasingly clouded. Rather, M usharraf's decisions in regard to counterterrorism strategy since 2001, although publicly perceived as personal dicta, invariably reflected the consensus among the corps commanders of the Pakistan Army and, hence, represent the preferences of Pakistan's military-dominated state. In other words, even if M usharraf were to suddenly exit the Pakistani political scene at some point, Islamabad's currently disconsonant counterterrorism strategy would still survive so long as the men on horseback continue to be the principal guardians of national security policy making in I slamabad. Because it is unreasonable to expect that the uniformed military will give up its privil eges in this regard anytime soon- even if a civilian regime were to return to the helm in the future- the internally segmented counterterrorism policy currently pursued by Pakistan will likely persist for some time to come.

Even if it could be imagined that a civilian dispensation could wrest some control of Pakistan's national security policy from the military, it is not at all certain that the current 
strategic direction would change dramatically: a civilian regime would probably have greater incentives to combat all sectarian terrorist groups more evenhandedly, but that too is uncertain. After all, both the Pakistan People's Party led by the late Benazir Bhutto and the Pakistan M uslim L eague led by $\mathrm{N}$ awaz Sharif have had problematic Islamist political allies in the past and, depending on the political exigencies of the moment, could harbor incentives to give even sectarian or otherwise radical entities a breather from prosecution, although that would likely be justified as only a temporary expedient. Both civilian parties historically al so permitted the Pakistani military and intelligence services to aid, abet, and arm the terrorist groups operating in Kashmir and el sewhere in India, sometimes because they were simply powerless to prevent it but at other times with their full knowledge and consent. It al so ought not to be forgotten that even a radically atavistic Islamist group such as the Taliban was raised, promoted, and unleashed by the civilian government of the late Benazir Bhutto (during her second term in office from 1993 to 1996) with the full collaboration of the Pakistani military and intelligence services - and that the Taliban continued to receive complete moral and material support under her civilian successor, the then prime minister, N awaz Sharif.

Both the principal civilian political alternatives in Pakistan would likely continue to prosecute the current antiterrorist operations against al-Q aeda because there seems to be a fragile consensus among Pakistani political elites that this group remains a grave threat to both their country and the international community. This fact, however, only underscores the continuity that is likely to persist in Pakistan's approach to counterterrorism even if a civilian government were to ascend to power in Islamabad. Although there are likely to be differences in style, nuance, and emphasis, the weaknesses of Pakistan's moderate political parties, I slamabad's enduring interests vis-à-vis Afghanistan and India, and the likely inability of any civilian government to exercise comprehensive control over the Pakistani military and intelligence services all combine to suggest that dramatic changes in attitude and performance toward the Taliban and the terrorist groups operating on Indian soil may not be forthcoming. And, although sectarian groups within Pakistan may be pursued more uniformly and hopefully just as resolutely as the war against al-Q aeda, the net deviation from M usharraf's currently segmented antiterrorism policies may be either too subtle or too insignificant to really matter. ${ }^{34}$

Ironically, the Bush administration itself bears some responsibility for reinforcing M usharraf's original instincts and entrenching what has now become the enduring Pakistani calculus. Although President Bush affirmed in the aftermath of the September 11 attacks that his war on terrorism would be total and that states supporting terrorist groups would be required to divest themselves of these entanglements decisively or face America's wrath, his own government never implemented his stirring vision in regard to Pakistan. Rather, during the Indo-Pakistani crisis of 2001-2002-a key moment of truth for Pakistan and its future course in the war on terror-successive U.S. intermediaries visiting the subcontinent pursued an approach that only permitted Islamabad to conclude that the war on terrorism was in fact eminently "divisible." 35 By not pressing Pakistan to relinquish all its terrorist clients once and for all during that crisis- as Washington had previously compelled Islamabad to forsake the 
Taliban on September 13, 200136 - the U nited States lost a momentous opportunity to help Pakistan rid itself of its long addiction to terror. Instead, the administration's diplomacy, by declining to hold M usharraf accountable for breaching his serial promises to end Pakistani support for terrorism, enabled Islamabad to infer that so long as operatives belonging to "terrorist groups of global reach"- meaning al-Q aeda-were being regularly apprehended by Pakistan, the ISID 's links to, and protection of, other regional terrorist organizations would not become a critical liability in U.S.-Pakistan relations.

The liberties thus afforded Pakistan in regard to sustaining its ties with local Kashmiri terrorist groups during the initial phase of the global war on terror consequently reinforced Pakistan's inclination to treat the Taliban remnants similarly. This blunder had few consequences as long as the Taliban movement was in remission, but it has proved to be a most costly lapse on the part of the U nited States because the sanctuary afforded by Pakistan to the Taliban - and especially its leadership-since 2002 has only permitted the group to rejuvenate and, once again, to begin offensive operations in Afghanistan that, in effect, threaten to undo the gains secured by the early victories in 0 peration Enduring F reedom. ${ }^{37}$

The U.S. neglect of the early Pakistani decision to ignore the Taliban as a target of counterterrorism operations can be explained only by the administration's single-minded concentration on the war with al-Q aeda. ${ }^{38}$ This obsession was no doubt justified at the time, but its inadvertent consequences have now come back to haunt the United States, N ATO, Afghanistan, and the ongoing military operations associated with O peration E nduring F reedom more generally. By failing to recognize that the early immunity provided to the Taliban would eventually complicate the effort to defeat al-Q aeda-if for no other reason than that these two groups remain geographically commingled and because Taliban endurance in southern and eastern Afghanistan and in the FATA is an essential precondition for al-Q aeda's survival - the administration lost an opportunity to consolidate its political and military gains in Afghanistan while simultaneously compelling Pakistan to hasten its march away from extremism.

The Bush administration has now begun to press M usharraf to actively interdict the Taliban - an issue that did not become the subject of high-level U.S. demarches before 2005-2006 - but it is not certain that, even if responsive Pakistani counterterrorism actions were to be mounted today, they would be as effective as they could have been had they been pursued in the administration's first term. This is because Pakistan's own current intelligence capabilities with respect to the Taliban are probably not as strong as they were when M ullah 0 mar and his associates were first ejected from Kabul.

Although it is certain that Pakistani information about the Taliban and their leadership is still better than that possessed by other intelligence agencies, including those of the U nited States, the probable atrophy of Islamabad's connections during the past several years of the war on terror, the strong and growing antagonism within Pakistan toward M usharraf's counterterrorism policies in the FATA, and the increasing opposition from Pakistan's fundamentalist political parties and their social bases of support toward M usharraf's domestic and foreign

carnegie endowment for international peace 
policies all viciously interact to increase the risk that belated Pakistani actions against the Taliban, including its leadership, may end up being far less succesfful than they otherwise might have been if executed a few years earlier. And that, in turn, implies not only that the challenges of defeating the Taliban are from a historical perspective rooted in fateful U.S. decisions to treat the Kashmiri terrorists differently when the administration should have done otherwise, but also that Washington ignored the Taliban until it was too late. 


\section{Explaining Pakistan's C ounterterrorism Performance}

The Afghan government's dissatisfaction and now increasingly the American polity's displeasure with Pakistan's performance in counterterrorism operations are conditioned considerably by the perception of Pakistan's unwillingness to crack down on terrorism comprehensively. This is a serious and, in actuality, complex charge.

By all accounts, President M usharraf himself is strongly committed to purging both al-Q aeda and the Taliban. The imperatives of eliminating al-Q aeda are obvious: Pakistan was never directly a sponsor of thisgroup in Afghanistan, and destroying its network remains the sine qua non of the lucrative Pakistani counterterrorism partnership with the U nited States. M usharraf also remains personally opposed to the political philosophy represented by the Taliban. He has repeatedly identified the "talibanization" of Pakistan as the most pressing threat facing his state, but whether this translates into a decision to physically apprehend or eradicate the Taliban cadres, and especially their leadership, is less clear. ${ }^{39} \mathrm{D}$ rawing a distinction between "diehard militants and fanatics," who "reject reconciliation and peace" and accordingly must be targeted even though they are hard to find, and the larger Taliban cadres, "most of [whom] may be ignorant and misguided" but "are a part of Afghan society," M usharraf has urged Kabul, Washington, and the larger international community to begin instead a campaign of reconciliation with the Taliban focused on "winning [their] hearts and minds." 40

M usharraf's attitude toward the Taliban thus remains complex and multifaceted: he clearly detests their worldview, referring to talibanization as a species of extremism that "represents a state of mind and requires [a] more comprehensive, long-term strategy where military action must be combined with a political approach and socioeconomic development." He is also opposed to what he calls "terrorist elements and foreign militants" within the movement, which he acknowledges "must be dealt with a strong hand."41 M usharraf argues, however, for peacefully integrating the Taliban's rank and file into civil society, a judgment that is premised heavily on the belief that these elements are merely misguided miscreants rather than implacable foes.

The nucleus of military officials around M usharraf appears to reflect his own sinuosity. While all senior Pakistani military officers are agreed that the al-Q aeda presence in the FATA must be eliminated, there is a considerable diversity of views in regard to the Taliban. Although many feel that the optimal outcome for Pakistan would be simply a Taliban that progressively lose their effectiveness and support and thereby fade into obscurity- a finale that would spare Pakistanis the distasteful obligation of having to turn their guns against their old clients—others are conflicted about these reactionaries for different reasons.

To begin with, many officers are disenchanted by Washington's approach to managing the larger issues associated with Afghanistan's political reconstitution. Since the emergency loya jirga held in 2002 and the subsequent Afghan presidential election of 2004, these officialshave 
been dismayed by what they perceive as the U.S. partiality toward the D urrani Pashtuns, who have traditionally been the privileged political elite in Afghan society (and from whose ranks, through the Popalzai tribe, emerged President H amid Karzai). The calculated neglect of the G hilzai Pashtuns - who are primarily rural and uneducated peasantry and who constituted a critical source of manpower for the Taliban cause- grates on many Pakistani national security managers not only because they believe that the continuing alienation of the Ghilzai feeds the Tal iban ranks but al so because it represents an enduring and deliberate disregard of their own clients in intra-Afghan politics. Thislatter consideration is significant because it has the effect of portraying Islamabad as feckless and incapable of influencing U.S. policy in directions more helpful to its friends despite Pakistan's large investments in the U.S. war on terror.

When these concerns are added to other strategic calculations about protecting the Taliban as a hedge against either the failure of the Karzai regime in Kabul or the dreaded prospect of increasing Indian influence in Afghanistan, the senior leadership of the Pakistani militaryas well as President M usharraf- believe they have good enough reasons to avoid targeting the Taliban comprehensively in the manner sought by both Kabul and Washington. ${ }^{42}$ The dangers of a heightened and targeted anti-G hilzai campaign leading to a political mobilization that renews the demand for an independent "Pakhtunistan" further exacerbate the fears of senior Pakistani military officials. Because the status of the Durand Line separating Afghanistan and Pakistan is still formally contested by Kabul, any provocation that results in strengthening the political dimensions of Pashtun solidarity among the tribes living on both sides of this boundary is viewed immediately as a potential threat to the territorial integrity of Pakistan. With the vivisection of 1971 indelibly emblazoned in the consciousness of the Pakistani military, senior commanders are extremely reluctant to embark on any military operations that would aggravate the local Pashtun tribes in the FATA and provoke them into making common territorial cause with their confreres on the other side of the border against the Pakistani state. 43

While ambivalence about the Taliban at senior levels in the Pakistani military thus has both strategic and self-interested dimensions, other more prosaic, but tactically important, considerations al so play a role. Recognizing that the Tal iban are essentially G hilzai Pashtuns with deep consanguineal ties to the tribes that have dominated the FATA for centuries, many Pakistani commanders are afraid that any continued large-scale military presence in the area, especially if exemplified by massed infantry operations of the kind mounted in 2002-2004, will only further inflame tribal sensitivities and diminish cooperation between tribal leaders and the armed forces, a cooperation that is absolutely necessary if the armed forces are to successfully apprehend the "terrorist elements and foreign militants" located in their midst. Although such embitterment has al ready occurred with problematic consequences for the success of antiterrorism operations, the leadership of the Pakistani military remains continually fearful that any added aggravation could lead to even greater tribal support for terrorist groups closeted in the area and a systematic denial of access to the military units tasked for operations therein. That such contingencies al ready appear to have materialized in the FATA 
suggests that the reluctance of senior Pakistani military leaders to violently engage the Tal iban will be reinforced even further. ${ }^{44}$

The most problematic elements within the Pakistani state, however, are probably the ISID officers in the field who were tasked with managing the liaison relationship with the Taliban over the years. Some simply feel loyalty to their old clients. 0 thers are content to exploit their leadership's own ambivalence about the Taliban. And some others are prepared to disregard leadership directives that enjoin interdicting the Taliban for either nationalist, ideological, or personal reasons - if they believe they can get away with it. W hatever the cause, the field operatives of the ISID are widely perceived in Afghanistan and in the U nited States as being less than fully committed to targeting the Taliban leadership in the manner required for the success of counterterrorism operations in the FATA and beyond. 45

At first sight, this is indeed a curious phenomenon because nothing in the organizational structure of the ISID suggests that it is either an autonomous or a rogue entity. The reportedly 10,000-strong ISID is staffed primarily by Pakistani military officers who are assigned to the service on deputation for a fixed period of time, and its leadership reports to the chief of army staff. The pay, promotions, and operations of the directorate are al so regulated by military rules and procedures, and by all accounts the Pakistan Army is a professional and bureaucratically efficient organization. C onsequently, the notion that ISID officers might be undermining policies pursued by the corporate leadership of the Pakistan Army appears counterintuitive at first sight and cannot be reconciled with the image of the Pakistan Army as a tightly centralized organization unless due credit is given to three realities. ${ }^{46}$

To begin with, the ISID, similar to many other intelligence organizations worldwide, has considerable operational latitude because of the nature of its activities in the covert realm: this includes access to financing "off the books," recruitment of agents from diverse sources to include those with unsavory backgrounds, and the systematic use of retired case officers who can conduct officially permitted operations while still providing the state with plausible deniability. Further, the implementation of many ISID operations is typically regulated by "directive control" as opposed to "detailed control," where field officers have the flexibility to accomplish strategic goals without having to secure prior approval of every particular from their superiors. And, finally, because ISID is simultaneously an external intelligence organization as well as a coercive instrument for implementing the preferences of military authoritarianism in Pakistan, M usharraf's management of this organization historically was manifested primarily through the promulgation of broadly defined policies, which were then implemented by a chain of subordinates who acted upon their understanding of his strategic intent and which simultaneously served to protect him from detailed knowledge of what may frequently have been highly troublesome activities.

Given these realities, the pervasive belief about ISID unreliability in the war against terror, and particularly against the Taliban, can be accounted for-despite the otherwise professional character of the Pakistan Army- only by one or more of the foll owing hypotheses: 
- That, despite their public claims, President M usharraf and his corps commanders are not yet committed to a policy of eliminating the Taliban and especially its leadership, root and branch; consequently, M usharraf and his commanders have not directed their military and intelligence services to systematically implement such a strategy.

- That, although President M usharraf and his corps commanders have settled on a strategy of eliminating the Taliban in principle, the operational predicates of this policy insofar as they apply to the leadership and other high-value targets have not yet been specified deliberately, thus permitting line-level officers to use their discretion when it comes to supporting or undermining particular counterterrorism operations.

- That, although President M usharraf and his corps commanders have settled on a strategy of eliminating the Taliban, to include its leadership and other "diehard militants," the large size and complex bureaucratic structure of the ISID permit its field officers, and especially the retired case officers still on its active payroll, to covertly ignore or violate leadership directives in many instances for nationalist, ideological, or personal reasons without fear of immediate retribution.

Whatever the real explanation for ISID recalcitrance may be- and the truth probably implicates a complex admixture of factors - the fact remains that the Pakistani campaign against the Taliban, and particularly its leadership, remains hobbled by convolution and hesitation. D uring the past several years, this has resulted in a deepening entrenchment of the Taliban and their sympathizers throughout the seven administrative agencies of the FATA and a growing expansion of their influence in the Tank, D era I smail Khan, and Swat Valley areas of the $\mathrm{N}$ orth West Frontier Province of Pakistan. ${ }^{47}$ Since $\mathrm{O}$ ctober 2007, for instance, the idyllic mountain region of Swat, barely 90 miles from Islamabad, has been occupied by self-styled "Pakistani Taliban" forces led by M aulana Q azi Fazlullah and his Tehrik-e-N afaz-e-Shariate-M uhammad (M ovement for the Enforcement of Islamic L aws) shaheen (fighters), who may be present in the area in greater than brigade strength. This development suggests not only that the Taliban movement and its sympathizers have moved beyond the traditionally stateless regions close to the D urand Line and into more settled areas within Pakistan but also, and more ominously, that what began as localized terrorist operations now threatens to evolve into a mature insurgency with the militant opposition able to eject government forces from a given territory, hold ground against state opposition, and coerce any local opponents into cooperating in order to sustain the newly secured safe haven. ${ }^{48}$

This intensifying tal ibanization in the sensitive areas of the N orth West F rontier Province has had diverse effects, including increased tensions with and between the traditional tribes resulting in both growing intertribal conflicts as well as bolder attacks on the Pakistan Army and paramilitary units in the region. In one dramatic encounter, more than three hundred Frontier Corps infantry men were taken hostage by local militants in August 2007 in South Waziristan, to be freed only after President M usharraf ignominiously released more than two dozen previously jailed Islamists, including M ullah O baidullah Akhund, the highestranking Taliban official captured by the Pakistani military. ${ }^{49} \mathrm{O}$ occasion, the tribal dissatis- 
faction with local talibanization, and particularly with some of the groups that support it, has been all to the good as, for example, when indigenous tribes in the Azam Warsak area of South Waziristan, supported by Pakistani military forces, attacked and expelled numerous U zbeks belonging to the Islamic M ovement of U zbekistan-a constituent of O sama bin Laden's International Islamic Front-who had settled in that locale. Unfortunately, such successful cleansing operations have been all too few. The main consequence of talibanization in the FATA instead has been, as one observer put it, to "provide more opportunities to the ISI[D ] to indirectly support some Taliban commanders sympathetic to Pakistan's objectives" in the ongoing war in Afghanistan. 50

The growing talibanization in the FATA and beyond has in fact resulted in the creation of a secure sanctuary for a variety of terrorist groups now conducting anticoalition military operations in Afghanistan. The evidence suggests that Taliban presence is strongest in the H elmand, Kandahar, Zabol, and O ruzgan provinces in southern Afghanistan and is either significant or conspicuous in Paktika, Khowst, Nangarhar, Konar, and N uristan provinces in eastern Afghanistan. In these areas, the Taliban have been able to deploy and sustain a large number of armed fighters in situ, which has permitted the movement to effectively displace the Afghan state by usurping its traditional functions such as maintaining law and order; extracting resources through taxation; administering justice through various adjudicative mechanisms backed by local militias; and dispensing welfare through the maintenance of schools, provision of social services, and the oversight of economic activities.

Performing these statal functionsis possible because the Tal iban undoubtedly continue to derive support from the G hilzai Pashtuns in Afghanistan; however, their record of increasingly ruthless retribution against any uncooperative tribal leaders does not hurt either. In thiscontext, the Taliban's ability to sustain the strong coercive presence they currently have in the southern and eastern Afghan provinces is enhanced considerably by their access to the safe haven in the FATA whence they can draw a large number of fighters, procure diverse kinds of ordnance and combat equipment, and tap into different streams of financial resources (including, but not restricted to, the zakat, the Islamic tithe) for the prosecution of the ongoing jihad against the Karzai regime and the foreign forces now present in Afghanistan. As one respected analysis has noted, "using [the sanctuary provided by the FATA] to regroup, reorganize and rearm," Taliban and other foreign militants, including al-Q aeda sympathizers, "are launching increasingly severe cross-border attacks on Afghan and international military personnel, with the support and active involvement of Pakistani militants."51

The fruits of this activity are witnessed in the deteriorating security situation in Afghanistan. Since the successful presidential election in O ctober 2004-an event that received the full support of the international community and heralded hope for a new Afghanistan - the Taliban insurgency has metastasized in scale, intensity, and fury. By 2006, the level of violence had increased dramatically, and previous operations that had been centered on assassinations, ambushes, and isolated hit-and-run attacks were now supplemented by more ominous tactics involving beheadings and suicide bombings, which historically have been utterly alien to Afghan culture. ${ }^{52} \mathrm{E}$ qually problematic has been the employment 
of ever more sophisticated improvised explosive devices, rockets, missiles, and man-portable air defense weapons, many of which continue to be fabricated in the arms foundries in the FATA but are now also increasingly supplied by al-Q aeda and foreign powers such as I ran. Even more remarkably, Taliban military operations have gradually evolved from singular covert attacks mounted by tiny groups to more complex, set-piece military operations undertaken by larger units, often involving attempts to seize and hold territory against superior forces, and employing more diverse and sophisticated crew-served weaponry, including indirect fire systems such as mortars and unguided rockets, as supplements to the traditionally ubiquitous personal firearms and direct-fire weapons. ${ }^{53}$

The strategic objectives of these new modes of warfare have al so become more complex. Rather than simply harassing the new Afghan government, which seemed to be the original intention, the current military activities of the Taliban are accompanied by sophisticated forms of information operations. Betraying evidence of lessons learned from their al-Q aeda accomplices, Taliban operatives use a variety of techniques ranging from sending crude lowtechnology "night letters" often conveying threats to specific individuals, to circulating DVDs and videotapes containing political propaganda, to exploiting more advanced technology such as radio, television, mobile and satellite telephony, and the Internet. In general, all these technologies are used to signal to the Afghan tribes that the return of the Taliban to power in Kabul is inevitable- despite whatever tactical losses might be suffered at the hands of N ATO forces in the interim- and that resistance or neutrality is therefore futile. As one analysis pointed out, even if this campaign does not persuade the Afghan people, "[t]he Taliban's own hearts and minds activities are now prolonging and exacerbating an al ready difficult insurgency problem for the Afghan G overnment and the International Security Assistance Force (ISAF) in the south of the country." 54

Finally, and perhaps most important, both the Taliban's information and its actual warfighting operations have moved beyond simple terrorist attacks aimed at disrupting the Afghan government toward more ambitious objectives revolving around the progressive domination of territory. Focused today primarily on NAT O 's Regional C ommand (South) for both symbolic and strategic reasons, the Taliban leadership appears intent on slowly seizing critical areas, district by district, through a strategy of covert infiltration in the Helmand, Kandahar, O ruzgan, and Zabol provinces as a prelude to wresting control of the city of Kandahar, which is intended to become the base for first dominating the South and eventually all of Afghanistan itself. If this evolution gradually succeeds, the Taliban insurgency in southeastern Afghanistan will have successfully metamorphosed from a guerrilla operation into something resembling a more conventional civil war with grave advantages to the militants in their struggle against the Karzai government in Kabul.

Although the safe havensin the FATA and the ability to derive local G hilzai support in the southern and eastern Afghan provinces (by providing the benefits of security, justice, and even development) have thus enabled a dramatic transformation in both the character of the ongoing Afghan war and the fortunes of the Taliban as an insurgent organization, a particularly dangerous consequence- especially from a U.S. perspective- has been the enhanced 
prospects for survival they have offered al-Q aeda. There is little doubt today that the survival of the Taliban sanctuary in the FATA (to include the talibanization of the wider area more generally) has been singularly responsible for the continuing regeneration of al-Q aeda as an organization because it has permitted the leadership and the operatives of this terrorist group, who are relatively smaller in number, to safely "dissolve" into a larger geosocial environment that is either hospitable to them directly or that protects them by disguising their presence amid a larger pool of Taliban adherents.

The al-Q aeda leadership, which is believed to be currently ensconced somewhere in the Bajaur Agency of the FATA, has further enhanced its immunity to interdiction by pursuing what appears to be a subtle strategy toward its Taliban hosts. Recognizing that the Taliban's Pashtun cadres remain the original denizens of the FATA and the adjacent areas in eastern and southern Afghanistan, al-Q aeda's overseers have been careful to tread lightly: despite their independent access to significant streams of foreign resources, they do not seem to have levied any excessive demands in terms of either hospitality or security, nor have they used their superior access to advanced military-technical capabilities worldwide to attempt any "takeover" of the Taliban movement. Rather, they appear to understand that an independent Pashtun insurgency that answers to no one but its own indigenous leadership stands the best chance of not only regaining control in Afghanistan but also securing the continued support of the tribal elements in the FATA, which in turn only better conduces to al-Q aeda's survival over the long term.

Al-Q aeda leaders thus have repeatedly endorsed the Pashtun leadership of the Taliban, centered on M ullah O mar's coterie, on many an occasion publicly, beginning in 2002 when $\mathrm{O}$ sama bin Laden conferred on M ullah $\mathrm{O}$ mar the title of $\mathrm{E}$ mir Al-M omineen (L eader of the Faithful). ${ }^{55}$ The increasing sophistication of the Taliban's military operations, the new integration of suicide attacks into its modus operandi, and its increasing emphasis on information operations for a group that historically despised the modern media also indicate that al-Q aeda elements continue to assist Taliban forces with at least technology and training, and possibly financial assistance, as partial recompense for the refuge they receive in the FATA as they continue to bide their time awaiting the reestablishment of Taliban control in Afghanistan. 56

Pakistan's failure to target the Taliban and especially its leadership since 2001 has, therefore, had several deleterious consequences. To begin with, it has resulted in the creation of a safe haven for various terrorist elements in the FATA, whence the Taliban war against the Karzai regime can be prosecuted and the al-Q aeda leadership protected and regenerated as it plans more catastrophic attacks on the West and on the U nited States in particular. It has also permitted the Taliban to nurture their indigenous bases of support within southern and eastern Afghanistan itself, whence they can slowly evolve into a tumorous state within a state. F urther, it has bred a cancerous nest of violent extremism inside Pakistan resulting in the rise of new Islamist militant groups, sometimes labeled the Pakistani Taliban, that are either sympathetic to or affiliated with al-Q aeda and committed to waging a holy war against the Pakistani government, the liberal elements in Pakistani politics, as well as other foreign adver- 
saries such as India, Israel, and the U nited States. The invigoration of these indigenous radical outfits has in the process produced a new generation of foot soldiers available to different extremist entities throughout the country and strengthened the social bases of support for the otherwise marginal Islamist parties in Pakistani politics. Finally, it has added to the al ready long and intractable list of problems confronting Pakistan as it struggles to tran sform itself into a moderate and succesfful M uslim state: in particular, it has condemned the Pakistani leadership, including acknowledged moderate leaders like M usharraf, to prosecute antiterrorism operations under highly disadvantageous conditions and in an area that by history and tradition has long been lawl ess, has been bereft of any concentrated state penetration, and that had no regular military presence worth the name until recently, yet is dominated by those very groups that have strong ethnic and increasingly ideological ties to the same terrorist elements sought by the Pakistani state. 57

If the foregoing discussion amplifies how Pakistan's counterterrorism performance has been structurally compromised by motivational and institutional problems, this is by no means the whole story. An equally important source of inadequacy has been the operational complexity of the counterterrorism operations themsel ves and Pakistan's myriad weaknesses in coping with these challenges. These difficulties - three of which are illustrated in the discussion that follows - only complicate the challenges caused by the larger problem of whether Pakistan believes eliminating the Taliban decisively is in its national interest.

First, Pakistan's inability to secure the tactical intelligence required for successful counterterrorism operations against key Taliban and al-Q aeda elements in the FATA has now become painfully obvious. Although the ISID and the army's director general of military intelligence have primary responsi bility for the collection of targeting intelligence in the FATA, their ability to carry out these tasks has been severely hampered in recent times. In part, this is undoubtedly because many Pakistani intelligence officers are simply sympathetic to radical Islamist elements who have been their clients for many years. Even when this is not the case, however, state intelligence activities have been hindered by the peculiarities of the political structures in the FATA and the corrosive changes that have been occurring therein.

It is often insufficiently recognized that, although the tribal areas are physically located within Pakistani territory, they are not governed by either Pakistani laws and regulations or the political institutions normally associated with national politics. In fact, the relationship between these tribal areas and the Pakistani state is regulated not by any common laws but by formal treaties between the resident tribes and the federal government in I slamabad. The existence of such treaties exemplifies what two analysts have rightly labeled "the anomaly of [the] FATA":58 it signifies that the link between the tribes and the Pakistani government resembles one that exists between coordinate, and not superordinate and subordinate, political entities. This is further corroborated by the fact that these treaties not only guarantee the tribes' immunity to the codified laws and regulations that govern political life in the rest of Pakistan but also bestow on them exclusive responsibility for the management of their own internal affairs. With the exception of the Frontier C rimes Regulation, a written document more than a century old that elaborates the principle of settling disputes through arbitration 
by tribal jirgas, most of the governing rules in the FATA are essentially unwritten, being based on a combination of rewaj (tribal customs) and Sharia (Islamic law).

The foundation of maintaining order and authority in such a system, which is anchored in custom, tradition, and legal practices going back to the British Raj, lay in the inculcation of harmonious relations between the political agent-a mid-level civil servant with sweeping powers who, although deputed by the governor of the N orth West F rontier Province as the highest-ranking official representative in each tribal agency, wasultimately responsible to the federal government in I slamabad - and the tribal maliks, or elders, who managed tribal affairs day to day and who until 1996 were the only individuals permitted to vote in elections for Pakistan's $\mathrm{N}$ ational Assembly. The ties between the agents and the maliks were critical to the production of good intelligence: the agents disbursed the resources provided by Islamabad to acquire the information required to keep the government up to date about developments along the frontier, and the maliks used the subventions provided to buttress their own influence, access, and standing with the tribes they supervised. 59

Although it was possi ble to alter this traditional structure of management in the FATA, successive authoritarian regimes in Islamabad eschewed that al ternative because the system of direct control through the political agent invariably appeared more attractive to Pakistan Army leaders who were innately uncomfortable with the idea of democratic alternatives involving the introduction of universal adult suffrage, the development of representative institutions, and the presence of civilian political parties in local politics. As a result, the traditional governing mechanisms, centered on the interactions between agents and maliks against the backdrop of the privileges encoded in the old treaties, were only reinforced by Islamabad despite the fact that the bonds between these agents and maliks had became increasingly discredited because of the widespread corruption and politicization that came to characterize their relationship. 60 As a result over time, the tribes along the frontier no longer looked up to their own maliks as selfless leaders or to the political agents as fair representatives of a federal government that sought to advance their welfare.

By the time the 1980s set in, the anti-Soviet jihad brought about a further-and deadlier- acceleration of this crisis. E gged on by the initiatives of Pakistan's I slamist president, Zia ul-H aq, the FATA witnessed a steady social transformation that resulted in the traditional authorities - the political agents and the maliks - being slowly supplanted by new religious leaders, the maulvis, who viewed issues of political loyalty primarily through religious or ideological lenses. The progressive demise of the old social order thus made the long-standing Pakistani human intelligence collection apparatus dramatically ineffective as the radicalized maulvis, viewing the protection of the Taliban and al-Q aeda cadres in the FATA as a politico-religious obligation, appear determined to deny the Pakistani state the necessary information required to apprehend these targets. The widespread outcry in the frontier areas against the U.S. war in Iraq, coupled with the growing perception that M usharraf's prosecution of counterterrorism operations represents illegitimate support for a U.S. administration involved in a global anti-M uslim crusade, has only strengthened the determination of the maulvis and the new Islamists, who have filled the "power vacuum" 61 caused 
by the demise of the agent-malik relationship in the FATA, to protect the terrorist targets sought by Pakistan and the U nited States. ${ }^{62}$

The limitations of Pakistani technical intelligence capabilities in the context of counterterrorism operations also do not help matters any. As a matter of fact, Pakistan does have an impressive array of national intelligence collection capabilities. These systems, which are focused primarily on gathering signals and communications intelligence (SIGINT and COM INT), are largely under ISID control although the actual intercept operations are conducted by inter-services signals units that employ technical personnel drawn from the army's Corps of Signals, the air force, and the navy. For the most part, however, strategic SIG INT and COM INT collection in Pakistan- the intercept, analysis, and dissemination of electronic signatures and communications waveforms - is disproportionately oriented toward targeting India. Islamabad's most sophisticated assets, accordingly, focus on the detection, direction finding, surveillance, and intercept of the high frequency (HF), very high frequency (VHF), ultra high frequency (UHF), and satellite bandwidths used by Indian diplomatic and military communications. ${ }^{63}$ These resources, together with the tactical SIG INT and C OM INT systems possessed at the corps level in the Pakistan Army, make Islamabad certainly capable of monitoring the communication devices used by the Taliban and al-Q aeda, because these in fact most likely resemble those supplied by the ISID to various Kashmiri terrorist groups and recovered over the years by the Indian military. The insurgency in Kashmir reveal ed that Pakistanisupported terrorist groups in South Asia, including those operating in Afghanistan, generally use HF radio, satellite telephony, and cellular phones for long-range connectivity, with commercially available line-of-sight VHF and U HF radios produced by companies such as Yeasu, Kenwood, and I-C om for their operational and tactical communications. ${ }^{64}$

Targeting the communications traffic generated through these systems, however, requires Pakistan'snational and tactical collection assets to be systematical ly tasked for this purpose, but both Indian and Afghan military intelligence officials believe that $\mathrm{N}$ ew Delhi continues to remain a higher-priority target for Pakistani technical collection in comparison with either the Taliban or al-Q aeda. E ven when this is not the case, however, Pakistani surveillance systems may continue to be ineffective in the counterterrorism mission for many reasons. If Taliban and al-Q aeda operatives use low-power devices sporadically for tactical communications, the short range and random nature of these transmissions may defeat even a technically competent operator if no surveillance devices are in proximity to the threat. Further, sophisticated technologies such as frequency hopping, portable encrypted, or digital burst radios, many of which are available commercially, can be used to elude even skilled surveillance especially if the monitoring systems are not available or are not dedicated full-time to the mission. Finally, the increased use of the Internet by Taliban and al-Q aeda operatives, including their growing use of encryption software, makes it hard for the ISID to monitor such communications systematically because, in the absence of prior cueing, high-speed computation married to sophisticated search algorithms would be required if the relatively large volume of Internet traffic, even within an otherwise relatively low tele-density state like Pakistan, is to be succesfully monitored. 65 It is simply not clear whether Pakistan possesses such capabilities. 
In principle, U.S. advantages here could serve to compensate, but the growing appreciation of the capabilities of U.S. assets has resulted in these opposition forces- both Taliban and al-Q aeda-increasingly relying on more primitive but more secure means of communication, such as "snail mail" and human couriers, for their operational planning. This workaround, in turn, denies both Pakistan and the U nited States the kind of targeting data that might otherwise have become available through technical intelligence. ${ }^{66}$

Recognizing these problems, Pakistan has begun the arduous task of rebuilding both its technical and its human intelligence collection assets in the FATA. The latter capabilities are indeed the most critical, but these also take the longest to mature and to yield their fruit. $A$ long-term Pakistan Army presence in the FATA amid conditions of relative peace is, therefore, an essential precondition for Islamabad to be able to develop and consolidate an effective human intelligence network. The $\$ 750$ million U.S. assistance program to the FATA, if properly directed, could help considerably in advancing this goal of local stability; but the complicated and time-consuming nature of this endeavor, the uncertainty about the program's effective implementation, and Washington's failure to condition the availability of these funds on Islamabad's implementation of political reforms in the tribal regions- to include, inter alia, the drastic revision of the Frontier $C$ rimes Regulation; the elimination of the political agent as part of the larger process of integrating the FATA into Pakistan's N orth West Frontier Province under the full jurisdiction of the provincial and national legislatures and the judicial system; and the withdrawal of restrictions on political parties operating in the FATA with an eye to introducing conventional political institutions-imply that neither the U nited States nor Pakistan ought to expect quick breakthroughs in their efforts "to build confidence and trust between the G overnment of Pakistan (GOP) and [the] FATA tribal communities" 67 leading to the demolition of the al-Q aeda and Taliban networks that have regenerated in this area over the last few years. 68

Second, the arrival of the Pakistan Army in strength in the FATA has resulted in social disruptions that have undermined its counterterrorism effectiveness. Although the insertion of the Army's XI C orps and the SSG battalions into the autonomous areas was a brave and necessary decision of the part of $\mathrm{G}$ eneral M usharraf, it has nonethel ess eroded the delicate compact that previously existed between the FATA and the Pakistani state. The resulting alienation and resentment on the part of the indigenous population have been reflected in significant counterterrorism problems. The Pakistan Army- which draws its cadres largely from outside the FATA and is primarily non-Pashtun in composition-is a highly professional force, but its maneuver units have often been stymied by their inability to secure the cooperation of the local populace, which views it today as an unwelcome intruder. The army's SSG is very effective in tactical counterterrorism operations but, being an elite unit, is far too diminutive to make a difference at the theater level.

The F rontier Corps, which is composed primarily of tribal levies and is the resident paramilitary force, could be potentially the most effective element, but it is often compromised by its close ties with the local inhabitants. Riddled with sympathizers, inadequately motivated, suspicious of both Islamabad's and Washington'sintentions, poorly trained and equipped for 
counterterrorism operations, yet present in strength throughout the FATA, the F rontier C orps (along with its other local siblings such as the F rontier C onstabulary, the tribal police [khassadars], and tribal militias [lashkars]) represents the perfect exemplar of the structural challenge facing Pakistan's counterterrorism effort: its best local units, the ones that share affinities with the tribes they patrol and consequently the forces likely to secure potentially the most useful intelligence, are al so the fighting elements least able or willing to cope with the battlehardened terrorists they are deployed against. 69

U nfortunately, the infantry elements of the Pakistan Army that have been pressed into the fight have their own problems as well. U nlike the Indian Army, which thanks to two decades of combating Pakistani-supported subconventional conflict now has considerable counterterrorism skills, the infantry battalions of Pakistan's XI Corps are configured primarily as strategic reserves for possible conventional warfare against India. C ounterterrorism operations are not their forte, and, while they have done a decent job of learning by doing, they still betray a proclivity for operational responses that while sensible against a conventional adversary are less than effective (and, perhaps, even counterproductive) when dealing with irregular forces: large unit deployments, intense (and sometimes indiscriminate) employment of fire, and sledgehammer cordon-and-search tactics. ${ }^{70}$

While the attrition strategies of the Pakistani military have been criticized by many for their detrimental consequences, it must be recognized that these are not al ways attributable to the "self-proclaimed invincibility of the [Pakistani] armed forces."71 Rather, the hostile terrain in which counterterrorism operations are conducted and the unexpectedly heavy firepower that Taliban and al-Q aeda terrorists have mustered in the past have been the two factors most responsible for the military's recourse to the relatively coarse counterterrorism tactics that are invariably derided.

It is not difficult to sympathize with Islamabad's predicament. For starters, the topography of the FATA is incredibly inhospitable as far as counterterrorism operations are concerned. The general geography of the area is characterized by harsh, rugged, and inaccessible mountainous terrain with steep slopes being the rule rather than the exception. The crest elevations in the region vary from 3,600 meters to 4,700 meters in the Khyber, Kurram, and O rakzai agencies of the central FATA, dropping somewhat to between 1,500 meters and 3,400 meters in the southern agencies of $\mathrm{N}$ orth and South Waziristan. These mountain ranges running roughly from northeast to southwest function as a complex barrier that breaks up the terrain into numerous tiny basins or valleys that are dotted with minuscule settlements surviving either through livestock grazing, subsistence agriculture, or petty trade. The size of these settlements is generally very small, ranging from literally a few dozen people in some instances to $a$ few thousand at most in the largest hamlets. The lines of communication between these outposts are invariably tenuous, extending along the ridgelines of the adjacent mountains or traversing them through numerous passes, tracks, and trails, many of which support only pedestrian traffic or pack animals. Because many of these routes are intestinal and insignificant, they are often known only to the locals who, along with smugglers, drug runners, and 
arms peddlers, have exploited these conduits in the natural terrain to carry out their business undisturbed for centuries. ${ }^{72}$

These terrain features produce three significant operational consequences that have great impact on the conduct of military operations. First, the isolation of the hamlets amid craggy geophysical features and the small sizes of the populations sheltered within them make it virtually impossi ble for outsiders to monitor any personnel movement to or from these locations, especially if the transit occurs on foot, by animal, or by isolated vehicular traffic (where possible). This is especially true if the movement concerned occurs in adverse weather or at night. Second, the consanguineal character of the tribal populations living in these areas implies that strangers cannot travel within the area without being readily detected, and safe passage in such circumstances usually occurs only when the local inhabitants are persuaded about the alien's peaceful intentions through some form of attestation by individuals known to the resident tribes. Third, the distances between the populated outposts can be significant given the absence of paved or metaled roads and, consequently, quick movement across the terrain invariably requires either strenuous marches on foot on or off established paths (depending on circumstances) or the use of animals, accompanied by guides in most cases. In several locations vehicular traffic is in fact possible, but, because such movement invariably hews to well-established roads and pathways, covert entry and exit through such access routes is generally difficult.

This concatenation of features abundantly explains why Pakistani counterterrorism operations have often run into tactical difficulties requiring recourse to "excessive" force. The isolated setting of many FATA settlements where terrorist cadres find refuge essential ly prevents the Pakistani pursuers of the terrorists from being able to approach these local es clandestinely. E ven small commando units operating on foot are susceptible to premature detection by the locals, and the munitions and weapons required to be carried over the harsh terrain and along the great distances within the region often tax the abilities of even the fittest infantry units, which must conserve their strength for the arduous military action at the end of their insertion. This consideration invariably mandates traveling on established tracks and paths, but even off-track approaches do not provide any assurance that the attacking force will be able to close in on its target undetected.

Because the risk of compromise is consistently high, many terrorist refugees have been able to simply escape at the first warning of military units moving en route to their hideouts. Early engagements with the Taliban and al-Q aeda cadres who chose to remain bivouacked also reveal ed- often to the surprise of their attackers- just how heavily armed they were; in fact, the character of their military equipment could often make the difference in whether they chose to escape or stand their ground and fight. Whenever they settled upon fighting, their employment of heavy weapons was invariably made doubly effective by the natural advantages accruing to the defense especially in mountainous terrain-gains that were further magnified by the clever use of stealthy tactics, the cunning utilization of the surrounding topography, the erection of effective positional defenses, and the exploitation of the timely warning provided by the local inhabitants. 73

carnegie endowment for international peace 
The persistence of such challenges compelled the Pakistani military to seek operational work-arounds that offered some chance of success. The solution that proved most attractive in many circumstances was to forgo tactical surprise, which might have ensued from the exclusive use of small units relying entirely on covert foot penetration, in favor of larger operations that sought to exploit tactical superiority through the employment of heliborne elements for both the transportation of substantial strike teams to some location in proximity to their designated target and for the firepower required in support of the actual assault. Because the final engagement in such situations usually involved a heavily armed and a partially or fully al erted adversary - if the latter had not al ready escaped - the attacking Pakistani combat teams were often forced to employ even heavier weapons than might have been originally intended, including mortars, antitank recoilless rifles and guided missiles, field artillery, helicopter- and aircraft-fired cannon and unguided rockets, and occasionally even generalpurpose bombs delivered by tactical aircraft.

The lessons offered by such engagements since 2002 are stark and clear: unless the tribal populations residing in the FATA are sympathetic to the government and are willing to either warn the army of the militants' presence in their midst or desist from al erting the terrorists to the military's anticipated arrival in their hamlets, counterterrorism missions will either fail or be condemned to rely on even greater applications of brute force for their success. ${ }^{74}$

The inevitable, but unintended, consequence of implementing such solutions has been significant collateral damage among civilians in the tribal areas. The residents, in response, have reacted to these losses by mounting violent attacks on, and repeated seizures of, Pakistani troops and paramilitary forces deployed in the area. The more extremist outfits, to include alQ aeda elements, have sought to exact their revenge by undertaking lethal suicide attacks against Pakistani military and intelligence personnel both within the FATA and deep inside the nation's heartland in an effort to compel President M usharraf to terminate his counterterrorism operations conclusively. These continuing attacks on Pakistani military personnel have, by many anecdotal accounts, lowered morale within the frontline units now operating inside the FATA and caused increased desertions, suicides, and frequent discharge applications. ${ }^{75} \mathrm{~N}$ ot surprisingly then, these devel opments have induced deepened soul-searching on the part of local commanders who wonder about the strategic wisdom of the ongoing war on terror and question the benefits specifically accruing to Pakistan. The growing antagonism caused by the collateral damage associated with U.S. military strikesfrom the Afghan side of the FATA has not helped make the Pakistan Army's problems any easier in this regard.

Throughout Pakistani society in general, there is a growing weariness with the counterterrorism operations presently being waged on the country's soil. Recent polling, for example, suggests only weak support for using force against Islamic militants operating within Pakistan, and most respondents overwhel mingly oppose al lowing outside forces to combat alQ aeda on their national territory. A survey recently conducted by the Program on International Policy Attitudes at the U niversity of M aryland in collaboration with the U.S. Institute of Peace found that just 44 percent of urban Pakistanis favored sending the Pakistan Army to the tribal areas to "pursue and capture al Q aeda fighters," and only 48 percent would allow 
the Pakistan Army to act against "Taliban insurgents who have crossed over from Afghanistan." In general, the survey concludes that "Pakistanis reject overwhelmingly the idea of permitting foreign troops to attack al-Q aeda on Pakistani territory. Four out of five ( 80 percent) say their government should not allow U.S. or other foreign troops to enter Pakistan to pursue and capture al Q aeda fighters," and three out of four (77 percent) oppose all owing foreign troops to attack Taliban insurgents based in Pakistan. ${ }^{76}$ Other polls reveal similar levels of disenchantment with the U.S.-supported campaign against terrorism. 0 ne report summarized it:

... despite their own concerns about terrorism, Pakistanis overwhel mingly oppose U.S.led efforts to fight terrorism - six-in-ten (59\%) oppose America's anti-terror campaign, while only $13 \%$ back it. Like many other M uslim publics throughout Asia, the M iddle East, and elsewhere, Pakistanis also oppose other key facets of U.S. foreign policy. Three-quarters (76\%) say the U.S. should remove its troops from I raq, and a similar proportion (75\%) believe the U.S. and N ATO should withdraw from Afghanistan, which shares a 1,500 mile border with Pakistan.

But Pakistanis are not just worried about the use of U.S. force in neighboring countries. They also fear they could become a target. M ore than seven-in-ten (72\%) are very or somewhat worried that the U.S. could become a military threat to their country. And $64 \%$ name the U.S. as one of the countries posing the greatest potential threat to Pakistan, more than even long-standing arch-rival India (45\%), with whom Pakistan has fought three major wars in the last sixty years. ${ }^{77}$

M usharraf has attempted to cope with this increasing national weariness and to circumvent the problems caused by his army's operations, minimize its casualties, and soothe the roiling political environment in the tribal areas by episodic strategies of appeasement built around so-called peace accords with the pro-Taliban locals in South and N orth Waziristan.78 Under these accords, the indigenous residents were tasked with preventing cross-border movements of terrorists into Afghanistan and further attacks on Pakistani civilian and military targets. They were also to ensure either the ejection or the surrender of all foreigners, meaning the non-South Asian cadres loyal to al-Q aeda, from the FATA in exchange for which the Pakistan Army would withdraw to its barracks, suspend its combat operations against the terrorists, and defer to the tribes in regard to resolving disputes relating to the status of particular individuals.

M usharraf's understandable objective in pursuing such a solution was to restore the status quo ante- hold the tribes responsible for maintaining peace and security as they had done traditionally - but it was a strategy that was doomed to failure because it did not appreciate the extent of radicalization in the FATA and the tribes' new determination to protect their al$Q$ aeda and Taliban cortege against the Pakistani government and the $U$ nited States, which were viewed as the greater threats. Thus, although several tribal groups have sought to cooperate with the government in rooting out the radicals in their midst, the more extremist enti- 
ties, not surprisingly, used the breathing space provided by the accords to recruit, train, and rearm the terrorists in anticipation of a heightened and continuing campaign in Afghanistan. The Pakistan Army's attack on the Lal M asjid in Islamabad proved to be the proverbial straw that finally destroyed the charade embodied by the peace accords in the FATA, but the failure of these agreements has left $M$ usharraf in an unenviable limbo where neither peace nor war seems able to deliver the counterterrorism goals pursued by the Pakistani state. ${ }^{79}$

Third, the operational context surrounding the counterterrorism effort in the tribal areas and in Afghanistan has changed considerably - to the disadvantage of the Western coalitionsince $O$ peration Enduring F reedom began in 2001. To begin with, the Taliban movement, which was never a tight and cohesive political entity in any case, has become an even looser network of affiliated individuals and groups since it was forced from power in Kabul. Today, the Taliban "alliance" can be characterized as a disparate congeries of several elements united only by a common religious ideology, a desire to regain power in either Afghanistan or their local areas of operation, and a deep antagonism toward the United States and its regional allies. Several distinct elements can be identified in the current Taliban coalition:

- The leadership shura centered around M ullah O mar and his cohort in Quetta and the subsidiary war councils in Q uetta, M iran Shah, Peshawar, and Karachi;

- The Taliban cadres who survived the defeat in Afghanistan, which are loosely controlled by the regional shuras and continue to draw on the madaris in the FATA and the refugee camps in Pakistan for their continuing recruitment;

- The tribal networks of former mujahideen commanders like Jalaluddin Haqqani who operates in Paktika, Paktia, and Khowst provinces and provides a key bridge between al$\mathrm{Q}$ aeda and the Taliban; Gulbuddin Hekmatyar who leads the Hezb-i-Islami and operates in N angarhar, Konar, and N uristan provinces; Anwar-ul-H aq who leads the H ezb-i-I slami (Khal is) al so operates in the $\mathrm{N}$ angarhar area and is believed to lead the Tora Bora $\mathrm{M}$ ilitary Front; and Saifullah M ansoor, a veteran field commander who is known to be active in the eastern areas;

- The Pakistani Taliban commanders like Baitullah M ahsud, the chieftain of the M ahsud tribe in South Waziristan; M aulana Faqir M uhammad who is associated with the Tehrike-N afaz-e-Shariat-e-M uhammad and who operates in the Bajaur Agency; M aulana Q azi Fazlullah, also affiliated with the same group but operating out of Swat; M angal Bagh Afridi, who leads the Lashkar-e-lslami in the Khyber Agency and is believed to be part of a larger local opposition network led by M ufti M unir Shakir; and Sharif Khan and N ur Islam, tribal leaders who have demonstrated considerable operational effectiveness in South Waziristan;

- The drug lords in eastern and southern Afghanistan, especially in H elmand and Kandahar provinces, who are either taxed or willingly contribute revenues that are indispensable for the Taliban war against Kabul;

- The sundry former anti-Soviet commanders who control small groups of fighters and are engaged primarily in criminal activities such as bank robberies, kidnappings for ransom, 
and assassination of local officials while they simultaneousl y offer their services as guns for hire;

- The disaffected Afghan Pashtun tribes, most conspicuously the rural G hilzai, who, feeling disenfranchised in the current governing arrangements, continue to support the Taliban with manpower and sanctuary within Afghanistan; and, finally,

- Al-Q aeda, which, while distinct from all the foregoing groups in that its focus of operations remains the global jihad, nonetheless collaborates with the Taliban in order to assist the Taliban in recovering control of Kabul while it continues to preserve its sanctuary in the FAT $A$ in the interim.

The implication of such a diverse target set is that destroying the Taliban today has become much more difficult because its previously weak hierarchical structure has become even more diffuse, with truly diverse entities coordinating as necessary but with each al so carrying out its own local agenda.

This reality, in turn, implies that while some specific nodes in this network will have to be defeated "kinetically" if the Taliban threat is to be erased, these tactical successes will have to be procured despite the political hesitation in parts of the Pakistani state and the real operational limitations of the Pakistani military. The complexity of Islamabad's relations with many of the constituent elements in the Taliban coalition does not help either: although I slamabad may readily cooperate in targeting some of the Pakistani Taliban commanders, drug lords, petty former anti-Soviet captains, and al-Q aeda elements, the ties nurtured by Pakistan's military and intelligence services with the Taliban leadership and the tribal networks of key former mujahideen commanders make these targets relatively inviolate, at least in the near term. For understandable sociopolitical reasons, Pakistani leaders are also likely to find it very difficult to conduct any large-scale interdiction operations aimed at the Taliban foot soldiers and the disaffected tribes-even if only in the FATA- partly because of the unmanageable chaos that would ensue in a very sensitive area of great importance to the Pakistani state and partly because of the fact that the insurgents drawn from these groups today are truly protean, capable of participating in military operations when required but at other times fluidly mutating into ordinary tribals.

There is no doubt, therefore, that winning the war on terror in Afghanistan will require dealing with the sanctuary enjoyed by various militant groups inside Pakistan. But it is probably an exaggeration to conclude "that the solution lies not in Afghanistan, but across the Khyber Pass in Pakistan." 80 What happens in Afghanistan itself is critically important- not only in regard to ongoing military operations but, more fundamentally, in respect to reconstruction, economic development, nation building, and political reconstitution-because the counterterrorism campaign will not be won until the political environment in Afghanistan improves to the point where these insurgent forces are denied the conditions that allow them to survive and flourish. As $G$ eneral James $L$. Jones succinctly stated in his testimony before the Senate Foreign Relations C ommittee, "I am convinced that the solution in Afghanistan is not a military one."81 
It is in this context that Afghanistan's—and not just Pakistan's — political failures are particularly galling. D espite the advances in developing a constitutional government in Kabul with strong international support, the Karzai regime has turned out to be conspicuously ineffective. The inability of the government to deliver basic services, education, justice, and economic development, even in those areas not directly threatened by the insurgency, has fueled great frustration with President Karzai throughout the country. The growing corruption witnessed at all levels of government only exacerbates this resentment. And the runaway upsurge in poppy cultivation, which in 2006 yielded an all-time-high output of 6,100 metric tons, has resulted in a situation where "militia commanders, criminal organizations, and corrupt officials have exploited narcotics as a reliable source of revenue and patronage, which has perpetuated the threat these groups pose to the country's fragile internal security and the legitimacy of its embryonic democratic government."82 The complexities of intra-Afghan politics only compound the situation further: many Pashtun groups, for example, stung by the government's inability or unwillingness to address their specific grievances, often view the local insurgents as more effective instruments for achieving their immediate security or developmental goals. Any efforts made by the government to assuage Pashtun bitterness directly, however, complicates its relations with the non-Pashtun groups, who are apt to see most initiatives aimed at bolstering central authority, reinvigorating the traditional Pashtun tribal structures, and negotiating with Pakistan as evidence of a surreptitious attempt to reassert Pashtun hegemony over the rest of Afghanistan. 83

The Karzai government has thus far not succeeded in steering clear of these competing pressures, and its sharply alternating policies have not helped its standing either. Its most recent stab at neutral izing the growing insurgency by implementing a reconciliation program involving the "moderate Taliban" is a good example. ${ }^{84}$ After resisting such an idea for a long time, in part because of opposition from former $\mathrm{N}$ orthern Alliance figures supportive of the government, President Karzai changed course and embarked on an effort to reintegrate the less extreme Taliban members into the national mainstream. The idea is indeed sensible in principle but difficult to implement successfully in practice. That President M usharraf is its most ardent advocate has not raised the credibility of the program particularly, because it is often viewed in Afghanistan as a Pakistani stratagem to evade fulfilling its obligations to erase the insurgent sanctuaries in the tribal areas. In any event, the notion of reconciling moderate Taliban into Afghan society, while certainly commendable if it is understood to mean coopting the poor and disenfranchised confederations such as the G hilzai, is invariably tricky and possibly even counterproductive because of the difficulties of distinguishing genuinely alienated individuals, who might be desirous of integration, from their more diehard and utterly intractable counterparts. O ne very thoughtful analysis concluded:

While more efforts should have gone into reconciliation in the early days, seeking to quell the insurgency now by rewarding criminal behavior would only perpetuate a culture of impunity and betray the trust of those who have backed the new, democratic, participatory institutions. It appears that the concept of reconciliation is being used 
interchangeably with amnesty. While such compromise may bring some measure of short-term relief, it would ultimately do nothing to break the cycle of violence. ${ }^{85}$

N ot surprisingly then, this Program Takhim-e Solh, which translates roughly into the Strengthening Peace program, has not been a noteworthy success. It does not appear to have made any significant dent in the manpower available to the insurgency, even as it has increased the fissures between Karzai and his non-Pashtun allies, has created new political threats to his 2009 presidential ambitions, and has failed to undermine the Taliban's social base of support in the interim.

O ne news report summarized the current crisis within Afghanistan laconically by declaring: "G overnment corruption and poppy cultivation are rampant and public services remain a wreck; food prices are soaring, unemployment remains high and resurgent Taliban forces in the south are pressing toward th[e] capital." 86 D efeating this last threat obviously represents a classic chicken-and-egg dilemma: Taliban resurgence prevents the Karzai regime from effectively extending central control in the east, south, and southeast of the country, while the lack of effective state presence in these areas is precisely what makes the Taliban's return possible in the first place. U nfortunately, the three critical elements that could help Afghanistan break out of this cruel trap are constrained for different reasons.

To begin with, and as the foregoing discussion has elaborated, Pakistan is hobbled by political hesitancy and myriad operational limitations.

To make things worse, N AT O forces in Afghanistan are constrained by various "national caveats," that is, operational restrictions that prevent the alliance's International Security Assistance Force (ISAF) from undertaking the necessary combat operations required to prevent the Taliban from consolidating their foothold in southern and southeastern Afghanistan. Although ISAF isformally charged with the provision of security throughout Afghanistan, the main thrust of its effort revolves around supporting the approximately thirty-four provincial reconstruction teams (PRTs) operating throughout the country. 87

The PRT s are joint military-civilian units of between sixty and one thousand personnel engaged in reconstruction activities aimed at enhancing local security in order to permit the larger nation-building exercise to succeed. This essentially humanitarian mission, however, presumes the consent of local residents for its success and requires the PRT to be neutral and impartial with respect to any overarching political rival ries that may otherwise characterize its operating environment. The PRT is supposed to be robust enough to defend itself against attack, but it is emphatically not intended to be the spear point of change through offensive military action. Although the vision underlying the PRT is defensible, the fact that the social change it engenders has consequences for the local balance of power within Afghanistan implies that its activities are entirely unwelcome to those who oppose the larger nationbuilding project. Consequently, the PRT s specifically and the international community's reconstruction activities more generally have become the target of concerted attacks by Taliban and al-Q aeda forces, especially in southern and eastern Afghanistan. It is in this context that the national caveats handicapping ISAF — some seventy-one at last count- become 
relevant because they prevent the various contingents that compose the 38,000-strong force from effectively engaging the adversary as required in accordance with tactical necessity. 88 Thus, although ISAF 's area of operations has now extended to all of Afghanistan thanks to its stage 3 expansion to the South and its stage 4 expansion to the East, the differential rules of engagement under which each national contingent now operates ensures that its full combat power cannot be brought to bear uniformly over the entire battlefield - to the obvious advantage of its Taliban and al-Q aeda adversaries.

To make things worse, although ISAF is declared to be N AT O 's highest-priority mission, the alliance has had enormous difficulty convincing its member states to make the requisite contributions of manpower, equipment, and finance to secure victory in the combat operations in Afghanistan.89 As things stand today, N ATO fields some 1.2 soldiers per thousand Afghan inhabitants. Even if the 85,000 Afghan security personnel and the 12,000-odd U.S. forces dedicated to $O$ peration Enduring F reedom are added to the number, the ratio of security forces to population hovers at about 4 soldiers per thousand inhabitants. This level of force presence is abysmal, given that a considerable body of research suggests that successful nation-building operations require at least 10 soldiers per thousand inhabitants, and preferably 20 soldiers per thousand inhabitants if there is an active conflict. 90

N ATO thus far has simply not been able to contemplate, let al one provide, combat forces at anything approximating these levels required for success in Afghanistan. The British, the $C$ anadians, and the Dutch have supplied the largest contingents actually involved in combat operations; although the Germans and the Italians have a significant presence, they are not involved in active combat. The French, too, while politically supportive of the ISAF mission in Afghanistan have declined to support the effort through either enhanced contributions or a restructuring of their current force posture. Although French forces remain among the most capable units within ISAF, the thousand-odd troops currently present in Afghanistan are deployed in the relatively secure areas in and around Kabul, with Paris continuing to resist NATO entreaties to dispatch these forces to the eastern and southern areas of Afghanistan where the Taliban opposition is most active.

The N ATO presence in Afghanistan is thus characterized by a curious paradox: the most capable E uropean states, largely those in western E urope, have simply declined to make the robust contributions required to win what is universally acknowledged as the "good war," while the alliance's newest entrants from eastern Europe appear far more willing to contribute to the ISAF effort even though they lack the depth of national and military resources possessed by their western European counterparts. Although the early U.S. disinclination to involve N ATO in Afghan peace operations played some role in sustaining this paradox, the later E uropean disenchantment with the U.S. war in I raq, Washington's treatment of terrorist detainees, and the U.S. emphasis on attacking the adversary as opposed to protecting the population all appear to have contributed toward the western European inclination to stay aloof from any war-fighting entanglements.

This reluctance to contribute on the part of the stronger E uropean allies is al so reinforced partly by the presence of competing security priorities and the remarkably weak domestic sup- 
port for any foreign military operations. ${ }^{92}$ Above all else, however, it is owed to the alliance's failure to create a consensus on the implications of a failure in Afghanistan for European security; the lack of a clarifying continental debate on the goals, strategy, and tactics associated with winning the war against al-Q aeda and the Taliban; and the stunning unwillingness on the part of the wealthier "post-heroic" 93 European states to actually fight a war that would require them to expend blood and treasure by remaining ensconced, deployed, and operating with their full panoply of military capabilities in southern and eastern Afghanistan until the adversary is eventually routed.

Finally, the principal combatant elements conducting O peration Enduring Freedom, through war-fighting actions against the al-Q aeda and Taliban forces in Afghanistan, are al so handicapped by several limitations. Among the most important of these is the availability of deployable troops. The 10,000-odd soldiers that the U nited States contributes to this combat operation, supplemented by token forces provided by the U nited Kingdom, $\mathrm{C}$ anada, and a few others, are increasingly insufficient given the growing scale and intensity of the Afghan insurgency. Although coalition forces are superbly trained and equipped and have proved themselves devastatingly effective in combat with their Taliban adversaries, they are simply insufficient to maintain the large-scale presence that is now required to win the war in southern and eastern Afghanistan, given the virulence of the challenge.

In the initial phase of $O$ peration E nduring Freedom, when military operations essentially consisted of search-and-destroy operations that targeted roving bands of terrorists, the current force size was probably appropriate because the superior mobility, firepower, and training of U.S. forces permitted them to sanitize large areas of territory despite their relatively small numbers. With the Taliban insurgency now nourished by local roots particularly in the N imruz, H elmand, Kandahar, O ruzgan, and Zabol provinces, simply defeating the insurgents in battle is insufficient because they appear able to replenish their numbers relatively easily using both local recruits and imports from across the border, and, more important, they are able to return covertly to the contested districts after their tactically victorious U.S. adversaries withdraw to their rear bases. D efeating this strategy requires a long-term presence of military forces in situ, which the division-sized U.S. combatant elements simply cannot provide. ${ }^{94}$

N AT O's inability - and reluctance - to fulfill this role and to include combat operations whenever required merely compounds the problem with the result that the local inhabitants, especially those opposed to the Taliban, are compelled to make their peace with the insurgents merely as a means of preserving their security. The surreptitious return of the Taliban in this fashion to any given district invariably results then in the ejection of the nongovernmental organizations working therein, the interruption of state-organized developmental assistance, and a crisis in local governance - all of which exacerbate the vicious circle that further undermines security. Given this dynamic, there is good reason to fear that, just as in Vietnam several decades earlier, U.S. and allied military forces could win every tactical engagement with the Taliban and yet lose the general war for Afghanistan. .55

Attempting to defeat this problem with the small number of combatant forces available only ends up overusing them. The Fort D rum, $\mathrm{N}$ ew York-based U.S. 10th M ountain D ivi-

carnegie endowment for international peace 
sion, for example, has al ready deployed to Afghanistan thrice in five years, and when deployed in the field it is invariably overextended operationally because of the need to cover those alliance contingents that are unable to engage in combat operations when required because of their nationally constrained rules of engagement. The only solution to this problem will be to beef up the U.S. military presence in southern Afghanistan: this may necessitate deploying more troops and equipment but, more importantly, entails creating a dedicated U.S. command operating under N ATO aegis with full and exclusive authority to conduct the war as required without being hampered by the need to support the less able allied contingents.

The slow progress in raising the indigenous Afghan security forces has not helped either in the interim. Most NATO officials interviewed on this subject declared flatly that the Afghan $\mathrm{N}$ ational Police is currently incapable of satisfactorily performing even basic law enforcement functions and, further, that it would be a long time before the Afghan $\mathrm{N}$ ational Army would be capable of operating as a tactical partner with allied units in counterinsurgency operations and even longer before it could do so independently. Last, and despite many recent improvements, the coordination among the multiple national militaries engaged in reconstruction, counternarcotics, and counterterrorism in Afghanistan has simply not been as effective as it could be. In fact, problems of command and control among various coalition elements remain a serious and continuing impediment to the success of the Afghan stabilization effort. 96 The vicious interaction of these many problems implies that the chicken-and-egg dilemmas confronting Afghanistan in regard to security and state presence are unlikely to be resolved any time soon.

On balance, therefore, the failure to eliminate the al-Q aeda and Taliban cadres in Afghanistan is owed to a complex cluster of causes. Pakistan's initial reluctance to interdict the Taliban stragglers who settled in the FATA and the leadership shuras that found homes in Q uetta and el sewhere in Pakistan played an important role in permitting this organization to regenerate. This process has been aided, however, by Afghanistan's own missteps in governance, including the failure to deliver security and economic and social development as well as to limit the runaway expansion in the cultivation of poppy in southern Afghanistan. The Pakistani effort to systematical ly interdict al-Q aeda while simultaneously going easy on the Taliban is riddled with inescapable contradictions. Although this strategy provided some early and important fruit, its tensions are now exploited by both the Tal iban and al-Q aeda as well as by the vitally important tribal constituencies that are increasingly less bystanders than full participants on the wrong side in the ongoing war on terror in the FATA. The operational, technical, and organizational limitations of the Pakistani counterterrorism forces deployed in some of the most inhospitable terrain in the world provides the final component of the explanation for why I slamabad has not done better. There is thus no doubt that Pakistan's reluctance to prosecute counterterrorism operations indivisibly has played an essential role in the failures al ong the Afghanistan-Pakistan border, but it is by no means the whole story, and any political posturing that suggests otherwise contributes neither to our understanding of the problem nor to its resolution. 


\section{What $C$ an the U nited States D o?}

Any discussion of U.S. options in the circumstances discussed above must begin with a recognition that there are no alternatives to the policies currently being followed that are both good and radically different. Clearly, the status quo is becoming increasingly untenable. There is a growing conviction within the U nited States, in both the executive branch and Congress, that Pakistan must "do even more"97 than it is currently doing. As U nder Secretary of State R. N icholas Burns put it directly but politely, "we would like to see a more sustained and effective effort by the Pakistani government to defeat terrorist forces on its soil. Al Q aida remains a potent force inside Pakistan, as is the Taliban. D efeating these enemies is essential to our effort to defeat terrorism in South Asia and around the world."98

The current approach, which consists of the U nited States shoveling in large quantities of economic and military assistance and counterterrorism compensation funds as exchange for what are increasingly viewed as meager Pakistani counterterrorism successes, will soon reach the limits of political acceptability, if it has not already. ${ }^{99}$ Even the Bush administration, which has been M usharraf's strongest bastion of support, has begun to chafe privately about Pakistan's performance or the lack thereof. 100 The executive branch has been neither ignorant of nor oblivious to Pakistan's shortcomings in regard to counterterrorism, but it has sacrificed its ability to secure stronger Pakistani cooperation by speaking in discordant voices that fail to convey a clear and insistent message, by failing to maintain the proper bal ance between public praise and private pressure, and by becoming entrapped in a policy cul-de-sac that emphasizes inal terable political support for the person of $\mathrm{M}$ usharraf rather than support for him as a means to accelerate the political transformation of Pakistan and secure victory in the war against terror.

Blindly persisting with the current policy, therefore, will set the stage for a convulsive dénouement in U.S.-Pakistani relations if any of the terrorist el ements currently operating in the FATA (or in Afghanistan) manage to successfully unleash a catastrophic attack on the U nited States. Although the dangers posed by such a contingency are appreciated by the administration, the relative unattractiveness of all the al ternatives to the status quo only ends up reinforcing its durability, even though it is increasingly unpal atable and understood to be fraught with risks. TheU.S. H ouse of Representatives, for example, in early 2007 took the first tentative steps toward an al ternative strategy of conditionality by demanding that the administration certify that Pakistan was in fact "making all possible efforts to prevent the Taliban from operating in areas under its sovereign control"101 as the price for continued U.S. assistance. In late 2007, after M usharraf's imposition of the emergency in Pakistan, the U.S. Congress followed up with a more significant initiative: it withheld $\$ 50$ million of the Bush administration's $\$ 300$ million military assistance request until the secretary of state could certify that I slamabad had restored democratic rights, but, more important, it limited the use of the remaining $\$ 250$ million strictly to "counter-terrorism and law enforcement activities 
directed against al-Q aeda and the Taliban and associated terrorist groups."102 Although these actions confirm the growing congressional disgruntlement with Pakistan's counterterrorism performance, the conditionality they enjoin is, on balance, still token and modest. O ther analysts have proposed even stronger forms of conditionality, such as smart sanctions directed at the Pakistan Army, in an effort to make Pakistan more conscientious toward, among other things, its counterterrorism obligations. ${ }^{103}$ W hile these alternatives are no doubt wellintentioned, it is uncertain whether they are likely to be more successful in comparison with the status quo.

The Pakistani polity in general, and the army and intelligence services in particular, despite benefiting greatly from the most recent bout of U.S. assistance, are still deeply suspicious of long-term U.S. intentions in the region. $M$ any in the armed forces especially feel that they are already paying disproportionately for what is in effect "Washington's war" and that they will be compelled to cope with the lasting effects of the turmoil in the FATA and in Afghanistan long after the U nited States has departed the region. This fear, based partly on the experience of episodic U.S. engagement in South Asia, al ready conditions I slamabad's reluctance to do battle more energetically against the Taliban. Although enlightened Pakistani military officers, including President M usharraf and G eneral Ashfaq Kiyani, the new chief of army staff, recognize that defeating the Taliban and al-Q aeda is consistent with Pakistan's own self-interest in principle, they al so believe that the intensity of counterterrorism operations cannot be increased beyond what the domestic political traffic will bear because "a war of all against all" in the FATA and el sewhere would only exacerbate the internal polarization of Pakistani society, embolden the radical fringe within Pakistan to mount even more violent acts of terror in response or in sympathy, and threaten both the security and the wellbeing of the still largely moderate Pakistani population.

Any strategy of strong conditionality, even if only carefully targeted at specific institutions such as the army and intelligence services, would further deepen the resistance against effective counterterrorism operations and deeper collaboration with the U nited States within these establishments. The likelihood that conditional assistance and targeted sanctions would be viewed as confirming the U nited States to be an unreliable ally by the most important constituencies within the Pakistani state is what prevents the administration from even contemplating a shift away from the current status quo.

A third approach that has been articulated in recent months, especial ly by some D emocratic presidential hopefuls, is one of unilateral U.S. military action against terrorist groups within Pakistan. U nfortunately, none of those who advocate this strategy have explained how it would be integrated with the existing patterns of interaction with the Pakistani government. These are based on the fundamental premise that, al though I slamabad is still simultaneously part of the problem and part of the solution to terrorism, it is basically a friend of the U nited States that must be helped to wean itself off its existing dalliances with terrorism while it is assisted to protect itself from any terrorist depredations in the interim. It is possible that this premise underlying the current policy is fallacious, but it is nonetheless incumbent on the advocates of unilateral military action to clarify how their preferred policy prescription would advance 
the goals of both effectively eradicating the Taliban-al-Q aeda combine over the long term and assisting the transformation of Pakistan into a successful moderate M uslim state.

Such clarification is imperative because any policy based on the announced threat of unilateral military action within Pakistan (and possibly against Pakistani forces) is only likely to deepen the already strong suspicion within the Pakistani military aboutU.S. regional goals and strengthen the Pakistan military's resentments toward the United States. In such circumstances, it would not be surprising if the Pakistan Army and ISID became even more obdurate in regard to apprehending various terrorist cadres in the FATA because the reluctance to surrender these elements in the face of a possible U.S. attack inside Pakistan would only deepen. The idea of an announced policy of unilateral U.S. military action, therefore, has little to commend it, particularly because the president of the U nited States already possesses the capacity to exercise such options in an emergency.

If such a policy is adopted nevertheless at the declaratory level, despite all the disadvantages accruing to it, it is important to recognize that it will not subsist as a stable terminus. Rather, it will end up becoming only a waypoint along a very slippery slope toward a fourth policy alternative: the designation of Pakistan as an adversary of the U nited States, with all the resultant consequences that such an affirmation would bring in its trail. Whatever Islamabad's failings may be - and it is easy to concede that they are many - the prospect of having to treat a large and precariously poised M uslim state, armed with nuclear weapons and with an unsavory record of proliferation activities, as a mortal adversary should give pause to even the most jaded politicians. If such a contingency were thrust upon the U nited States through no fault of its own, the government of the day would have no choice but to cope with this horrendous predicament as best it could. In fact, in the immediate aftermath of the September 11 attacks, the Bush administration did contemplate the issue of how to deal with a collapsing Pakistan that might lose control of its nuclear arsenal and in the process lash out at the United States. ${ }^{104}$

Even if the solutions developed to deal with this eventuality were considered reasonably robust, no sane policy maker would want to do anything that contributes to such a contingency actually materializing. A policy that unilaterally targets Pakistan in any substantial way, even if only in the context of justified counterterrorism operations, could end up making exactly such a contribution. This approach would risk inflaming Pakistani public opinion, especially that at the extremist fringes; it would deepen the bitterness within the Pakistani military and intelligence services and strengthen their incentives to assist those terrorist groups that seek to inflict most damage on U.S. interests; and it would embarrass the mass of moderate Pakistanis, both within civil society and in the armed services, who believe that cooperation with the $U$ nited States represents the solution to both defeating terrorism, however slowly, and rejuvenating Pakistan as a succesfful state.

This net assessment of choices confronting the $U$ nited States suggests, on balance, that there are no good - and dramatically different-alternatives to the current policy. It is not surprising then that dealing with Pakistan has become a source of great frustration to those inside and outside of government because the current approach has not yielded successes as 
quickly as is necessary and few good alternatives appear to be in sight. While Pakistani prevarication in regard to counterterrorism is clearly one important reason accounting for the lack of accomplishment and, hence, ought to remain a source of continuing concern, there are no easy solutions to this problem, at least none that do not take the U nited States ever closer to that dreadful fourth alternative, an altercation of some sort with Pakistan. It is possible, perhaps even likely, that Pakistani officials who fulfill their counterterrorism responsibilities halfheartedly understand this dynamic very well and, accordingly, seek to exploit the U.S. aversion to a conflictual relationship with Pakistan to play both ends against the middle: collecting U.S. aid while protecting their terrorist clients because they are convinced that Washington would not risk stronger measures to end this charade because of the larger risks to the bilateral relationship.

It is al so easy to understand why critics of the administration's policies, suspecting that this is in fact the calculus of many Pakistani officials, advocate a more confrontational response since they believe that Pakistan's failure to perform al ready places I slamabad at odds with Washington. ${ }^{105}$ The critics' recommendations would be justified if it was in fact clear that the senior leadership of the Pakistani military was pursuing such a deliberate and calculated strategy to undermine U.S. interests through its recal citrance in the war on terror and that its feigned cooperation was only a subterfuge for a more pernicious agenda. On this central question, however, the evidence is not clear. Rather, the facts suggest that while some elements in Pakistani society-including in the army and in the ISID - would be content to see the U nited States fail because of what is perceived to be its myriad transgressions against M uslims worldwide, the majority of senior Pakistani military officers support the operations aimed at defeating terrorism, even if their fears about its domestic repercussions and larger U.S. goals, coupled with their pursuit of narrow regional interests, prevent them from offering their cooperation more wholeheartedly.

If this is a more accurate reading of reality, then the goal of U.S. policy must be to convince these elites that the conclusive defeat of even those who might have been their erstwhile clients is in their own enlightened self-interest. If interest does not move them sufficiently, then perhaps fear ought to: it is incumbent, in this context, that U.S. policy makers remind their Pakistani counterparts not simply that Islamabad continues to enjoy the administration's unqualified support-as they often do-but also that the growing discontent about Pakistani performance as expressed in the current election campaign ought to suggest that Washington's attitudes toward Pakistan could change quickly-and in the direction of unremitting hostility- if a catastrophic terrorist attack on the U nited States in the future was seen to have been made possible as a result of Pakistani negligence or connivance.

Apart from whatever U.S. policy makers may say to drive this point home, the best instrument for nudging Pakistan in the direction of effective counterterrorism performance still remains moving the bilateral relationship away from a "transactional approach" centered on "specific reciprocity." This approach requires Islamabad to perform certain desirable actions as a response to some tit-for-tat stimulus that offers either positive or negative reinforcement. Whatever the specific benefits or liabilities in the current congressional imposition of condi- 
tionality may be, such an approach is hazardous precisely because it reinforces awkward notions of specific reciprocity and makes them central to the evolving U.S.-Pakistan relationship. In point of fact, U.S. policy toward Pakistan should aim for exactly the opposite: it should be oriented toward constructing a "relational equilibrium" based on "diffuse reciprocity." Islamabad would thus pursue the right policies in the counterterrorism arena and el sewhere not merely because of the prospect of securing some immediate payoff but, instead, because the expectation of a steady and lasting partnership with the $U$ nited States propels it to act with rectitude, confident that its good conduct would lead to a wider institutionalization of trust that would pay for itself over time. ${ }^{106}$

Washington's policy, including congressional actions, toward Islamabad should focus on consummating a relationship of this sort while it remains cognizant that such a goal may prove eventually to be unattainable because of a variety of political deficiencies within Pakistan. It is not clear today, however, that the objective of a "relational equilibrium" with Islamabad is inevitably doomed to defeat. Consequently, the Bush administration ought to persist with its current emphasis on the noncoercive engagement of Pakistan at least so long as there is a reasonable hope that the transformation of Pakistan into a moderate M usim state is not a lost cause, that the M usharraf regime can be persuaded to expand its counterterrorism operations to those groups that have thus far remained beyond reach, and that the U nited States will have sufficient opportunity to switch to an alternative strategy before the present attempt at engagement is judged to have failed irremediably.

Admittedly, this is not an entirely satisfying solution because it still condemns the $U$ nited States to some variation of the status quo- "shifting gears, but not reversing course," as $D$ aniel $M$ arkey would phrase it 107 - but it is a variation that could make all the difference. Although the Bush administration and perhaps even the incoming administration will not enjoy the luxury of changing current U.S. policies toward Islamabad radically- that is, offering substantial assistance in exchange for continued Pakistani contributions to counterterrorism - it is worth introducing some modifications to the current approach. These modifications ought to include the following correctives.

First, speak clearly and forcefully in private to M usharraf and his cohort about U.S. frustrations with Pakistani counterterrorism performance in order to help them appreciate the prospective consequences of continued inaction for Pakistan and for U.S.-Pakistan relations. The current approach of "praising in public, pressuring in private" risks degenerating into a policy of "praising in public, acquiescing in private," with great danger to both U.S. counterterrorism objectives and improved U.S.-Pakistani relations. O dd as it may seem, the U nited States has never replicated the tough message sent to Pakistan on September 13, 2001, at any point thereafter, even though senior U.S. policy makers have at various moments since been extremely aggravated by the failures in Pakistan's counterterrorism performance. A continued unwillingness to confidentially send Islamabad the necessary messages of tough love not only will contribute to prolonging the deficiencies in Pakistani counterterrorism effectiveness but will, even if only unwittingly, conduce to the eventual meltdown in bilateral relations in case of a future catastrophic attack on the U nited States.

carnegie endowment for international peace 
Second, demand that Islamabad start systematically targeting the Taliban leadership as part of the current counterterrorism concept of operations. The Bush administration has succeeded in persuading Pakistan to step up its efforts at interdicting border crossings, but Afghan and N ATO officials assert that a significant number of successful insurgent infiltrations still occur at official crossing points al ong the Afghanistan-Pakistan border. This suggests that Pakistani border patrols are either ineffective or in collusion with at least some of the infiltrators, if it is assumed that some others would inevitably succeed in covertly eluding the surveillance maintained at border outposts for a combination of topographic and technical reasons. ${ }^{108}$ I slamabad has attempted to combat such crossings by building additional barriers such as berms and recently by ambitiously attempting to fence some sections of the frontier itself. The Indian experience in Kashmir has demonstrated that border fences erected in hostile terrain are conspicuously ineffective in preventing insurgent infiltration, even if the threat of colluding security forces is entirely discounted. The Bush administration, therefore, should continue to press Islamabad to improve its border control efforts, but it ought to dissuade Pakistan from overinvesting in such initiatives as fencing, especial ly if these are undertaken at the expense of targeting the Taliban leadership that, by a wide consensus, continues to operate from within Pakistan and in geographic areas that are far removed from the border itself.

Third, restructure the current counterterrorism intelligence liaison relationship between the U nited States and Pakistan in order to permit both the C entral Intelligence Agency and the war-fighting components prosecuting $O$ peration Enduring Freedom in Afghanistan to acquire greater insight into the existing terrorist networks operating within Pakistan. As Steve Coll elaborated in his superb study of the anti-Soviet jihad, the ISID traditionally was eminently successful in preventing its foreign intelligence partners from securing any access to its clients, assets, and networks, even when these were funded substantially by outside sources. ${ }^{109}$ There is no reason to believe that this pattern of operations has changed fundamentally today; if it has not, the U.S. intelligence community will continue to get less than what it requires for the success of U.S. objectives despite the great revitalization of U.S. overt and covert assistance to Pakistan.

Fourth, continue to assist Pakistan with the technology and the training to prosecute small-unit counterterrorism operations more effectively. M uch of the technology at issue is not particularly cutting edge and consists of transport helicopters, field radios, earlygeneration night vision equipment, and tactical vehicles. Such transfers should be sustained and ought to be supplemented by increased training, but only so long as key units such as the SSG continue to perform as resolutely as they have in the past. The improved training contemplated for the Frontier C orps and other paramilitary organizations charged with border patrol should also be accelerated.

The current U.S. military proposal to enlist and arm some key tribal leaders in the FATA and in Afghanistan to fight against al-Q aeda and the Taliban al so ought to receive careful and serious consideration. ${ }^{110}$ Although such programs al ways have risks, the dangers could be potentially worth the benefits in many cases. It is not often understood that even in a turbu- 
lent agency like Waziristan, where the tribal confederations are often irate and radicalized, there are several tribes, subtribes, and tribal leaders of extended families who oppose alQ aeda and the Taliban insurgency and are willing to cooperate with the Pakistani government if it can provide them with effective security and protection. In many instances, such individuals have only acquiesced to the insurgents because they had no choice or because the latter were able to better meet their security and developmental needs in comparison with the Pakistani government or the military. Identifying these groups and assisting them, by arming them if necessary through village self-defense units closely coordinating with the military, remains a good way to channel their frustration with the Taliban insurgency and the ongoing conflict and to incorporate them into the struggle against the more obdurate and intransigent al-Q aeda terrorists.

Whether such a solution is implemented in Pakistan or in Afghanistan, it should be pursued only if the following three conditions are judged to apply: the arming of the tribes serves to provide effective local security beyond the current capacity of the state, the groups so armed are relatively stable in social structure and in political orientation and are not ideologically radical ized, and the increase in tribal self-defense capabilities is undertaken in close and continuing collaboration with the national security forces and with the government.

Fifth, shift to an alternative modality of disbursing coalition support funds to Pakistan where reimbursements are tied to specific tasks and linked to the performance of specific objectives. 111 The current system of simply cutting checks for whatever bills are presented monthly by Islamabad as the costs borne for counterterrorism support engenders institutional corruption in the Pakistani military, destroys the integrity of the U.S. assistance program, and is unfair to the U.S. taxpayer. The current accounting practices used by the Pakistani military to justify its routine demands for reimbursement border on daylight robbery and would never pass muster in any serious oversight and auditing system. A reform of the coalition support reimbursement system would, therefore, not only better align U.S. financial burdens with the true services rendered by Pakistan but also ensure that U.S. military assistance would actually be used for counterterrorism efforts rather than diverted toward other programs while simultaneously serving as a subtle reminder to I slamabad that U.S. generosity cannot be taken for granted in the face of continuing prevarication. 112

Sixth, integrate the ongoing political transition in Pakistan-including the growing national clamor for a genuine return to democracy centered on an abiding rule of law-into the larger war on terrorism. Although the legitimacy of $M$ usharraf's rule and the character of Pakistan's apex governing arrangements were not initially central to either the war on terror or I slamabad's counterterrorism performance, both these variables have now become important to Pakistan's ability to win the struggle against Islamist extremism. The return of these issues to center stage has been provoked by a series of blunders perpetrated by $M$ usharraf himself. M usharraf's fateful decision to confront the Supreme C ourt, his efforts to forge a mutually self-serving agreement with the late Benazir Bhutto in order to secure an unchallenged extension of his own rule, his indefensible declaration of a political emergency in Pakistan, and finally the cataclysmic assassination of Bhutto that her followers widely attribute to the 
regime's negligence if not outright complicity have all combined to make M usharraf's own fate and, more important, the character of the future governing regime in Pakistan critical to the success of the larger war on terror.

There is absolutely no doubt that the reestablishment of a stable democratic order in Pakistan is essential to arresting the country's spiraling descent into extremism and disorder. The current confusion about which surviving provisions of the Pakistani constitution are truly overarching, the muddied division of power between the different branches of government and even among the various offices within the executive in Pakistan, and the simplistic conflation by the Bush administration of Musharraf's own struggle for survival and legitimacy with Pakistan's larger battle against radicalism and extremism have all combined to create a profound institutional turmoil that neither advances Pakistan's return to democracy nor enhances its capacity to combat terrorism successfully. Given this fact, a variety of commentators in the U nited States and elsewhere have declared, in Joshua Kurlantzick's words, that "the U [nited] S[tates] needs to abandon M usharraf today."113

W hile that sentiment is understandable, the prescription is misguided. The U nited States today has little choice but to support M usharraf, if for no other reason than that he remains essential to orchestrating an orderly political transition in Pakistan. Such a transition, which could take some time to conclude, is necessary to prevent any untoward disruption in the ongoing U.S. and Pakistani military operations related to counterterrorism; to permit the newlyelected civilian leaders to fashion fresh political arrangements that will define, among other things, the desired role of the military in the political life of Pakistan; and to provide the polity an opportunity to review the many modifications that have been arbitrarily grafted onto the Pakistani constitution over the years for their compatibility with the emerging national desire for a stable constitutionalism. Consequently, the administration ought to continue extending its support to $\mathrm{M}$ usharraf not simply because he has proved willing to advance certain common interests in the war against terror but, more important, because ironically he remains necessary to assuring the kind of democratic transition that stands the best chance of enduring in Pakistan. Toward this end, Washington ought to insist that M usharraf oversee a fully free and fair election unsullied by any irregularities so that its outcome authentically reflects the preferences of the nation in its entirety. And after the election the administration ought to encourage the emerging centers of power in Pakistan - the president, the prime minister, the chief of army staff, and the courts- to work as peaceably as possible while time, a gradually stabilizing political process, and the new prime minister and elected legislature, begin to define anew the structural framework by which Pakistan will be governed over the longer term. 114

Seventh, assist the Karzai government in Afghanistan in moving quickly to address its lacunae in governance, particularly with respect to security, economic development, and narcotics production especially in the southern provinces, by committing to a substantial increase in long-term assistance to Kabul. There is a large body of persuasive research coming out of the RAN D C orporation, for example, suggesting that foreign assistance at the level of at least $\$ 100$ per capita per year is a minimum for successful stability operations in the early years of 
nation building. It is truly tragic that despite there being a near universal consensus in the U nited States that Afghanistan represents "the right war for the right reasons," foreign assistance to this country even at its peak averaged only \$57 per capita per year. In comparison, the assistance levels associated with the relatively successful nation-building efforts in Kosovo and Bosnia were, respectively, $\$ 526$ and $\$ 679$ per capita per year. ${ }^{115} \mathrm{G}$ iven that the situation in Afghanistan is deteriorating but not yet lost- for which both C ongress and the administration ought to be thankful- those two branches need to recognize that a fickle effort will not save Afghanistan today nor increase the security of the U nited States in the stillincomplete war against al-Q aeda. Accordingly, the U nited States should at the very least support Afghanistan's reconstruction by doubling the current levels of U.S. assistance over the long term.

E ighth, challenge N ATO to live up to its collective security obligations by making the necessary manpower and material contributions to fight and win the war in Afghanistan. This requires, at the very least, meeting the force requirements identified in the ISAF operational plan, including by sending additional troops and combat equipment to Afghanistan. It will al so necessitate abolishing the currently promulgated national caveats that impede interoperability and prevent the alliance from undertaking those combat operations that will be essential if the Taliban-al-Q aeda threat is to be decisively defeated. Transforming N AT O 's mission from its current emphasis on predominantly soft approaches to defeating the counterinsurgency to something that accommodates this new direction will require a genuine debate within the alliance about its own role and contribution toward maintaining global stability, especially in those functional and regional areas that have a direct impact on E uropean security. Thusfar, NAT O has evaded the fundamental strategic questions associated with its Afghan mission. If the alliance, however, is to live up to its historic decision to invoke Article 5 of the Washington Treaty-a decision made with great courage and fervor on September 12, 2001- then this coalition, the strongest alliance in the history of man, must be able to demonstrate a commitment to both providing the resources and prosecuting the missions necessary to resolutely defeat those common adversaries now found in Afghanistan.

$\mathbf{N}$ inth, and finally, accelerate the raising of the Afghan N ational Army (AN A) as a hedge against the possibility that N ATO will fumble in the challenge of reorienting the ISAF mission as recommended. Although the existing effort to rebuild the 82,000-man ANA has been painfully slow, this failure is owed both to the fragmented approach to training the force, with different coalition partners being responsible for different kinds of training, and to the niggardliness in funding the effort. As things currently stand, the French oversee the training of staff, platoon, and company command officers; the British conduct initial infantry officer training and commissioning; and the $\mathrm{C}$ anadians oversee the combined training exercise that brings together trainee sol diers, noncommissioned officers, and officers in field maneuvers at the platoon, company, and battalion levels to certify them ready for operations. All these activities are coordinated by the coalition through the Combined Security Transition Command-Afghanistan and by the ANA through the newly formed Afghan National Army Training C ommand, a two-star authority that reports directly to the chief of the general staff.

carnegie endowment for international peace 
As the record of the past several years has demonstrated, progress has been painfully slow, and, if the training of the force- and even its expansion - is to be accelerated, a more radical solution must be contemplated. U nlike many of the N AT O contingents, which either betray a disinclination to fight or are prevented from doing so, the AN A is both willing to defend its country and is highly motivated to do so. All it needs are the resources, the training, and the equipment. C onsequently, the U nited States ought to give serious consideration to the idea of radically rationalizing the training program under possibly its own or another single national command and increasing the budgetary support significantly to enable the deployment of an even larger and more capable force than is currently intended-if the AN A is to be able eventually to protect its country effectively and independently. The U nited States should also unequivocally support the creation of an Afghan Army Air Corps capable of, at least to begin with, close air support for AN A forces operating in the field, air mobility operations for the rapid transport of troops and equipment from rearward bases to the front, and a reasonably sized heliborne medical evacuation capability for treating battlefield casualties.

These improvements to the current U.S. policy vis-à-vis Pakistan are indeed admittedly modest in comparison with some of the more drastic alternatives reviewed earlier. But they ought to help remind Islamabad that, if Washington were compelled to shift to some completely different strategy, it would certainly be costly for the $U$ nited States but it would be even more painful for Pakistan. Continuing on a course of action that would end up testing this proposition in practice is in neither Pakistan's interest nor America's. The necessity for a pointed reminder is therefore all the more urgent because even if the current regime centered on $\mathrm{M}$ usharraf is replaced by another military or civilian dispensation, there is no assurance that Pakistani motivations and performance in the counterterrorism arena will be radically transformed. 


\section{N otes}

1. "President Bush Welcomes President M usharraf to C amp D avid: Remarks by President Bush and President M usharraf of Pakistan in Press Availability," C amp D avid, June 24, 2003, www.whitehouse.gov/news/rel eases/2003/06/20030624-3.html.

2. O ffice of the Director of N ational Intelligence, "The Terrorist Threat to the US H omeland," N ational Intelligence E stimate, July 2007, www.dni.gov/press_releases/20070717_release.pdf.

3. For details, see the excellent survey by K. Alan Kronstadt, "Pakistan-U.S. Relations," CRS Report for Congress no. RL 33498 (Washington, D .C .: Congressional Research Service, O ctober 18, 2007), beginning on p. 50 and table 1, D irect O vert U.S. Assistance to Pakistan, FY2001-FY2008, www.fas. org/sgp/crs/row/RL 33498.pdf.

4. For O bama's statements, see D an Balz, "Obama Says He Would Take Fight to Pakistan," Washington Post, August 2, 2007; for Edwards on Pakistan, see "John E dwards' Speech on Terrorism," remarks by John E dwards, Pace U niversity, September 7, 2007, www.cfr.org/publication/14788/ john_edwards_speech_on_terrorism.html.

5. The most cogent and persuasive articulation of this judgment can be found in Seth G. Jones, "Pakistan's D angerous G ame," Survival, vol. 49, no. 1 (Spring 2007), pp. 15-32; and Barnett R. Rubin, "Saving Afghanistan," Foreign Affairs, vol. 86, no. 1 (January/February 2007), pp. 57-78.

6. Address by the President of Pakistan, G eneral Pervez M usharraf, to the N ation, September 19, 2001, Islamabad, in K. R. G upta, ed., International Terrorism: Response of India, Pakistan and The U nited States, vol. 5 (N ew D elhi: Atlantic, 2002).

7. The best analysis of Pakistan's relations with the Taliban can be found in Steve Coll, G host Wars: The Secret $\mathrm{H}$ istory of the C IA, Afghanistan, and bin L aden, from the Soviet Invasion to September 10, 2001 (N ew York: Penguin Books, 2005).

8. This information was formally conveyed to the U nited States by the G overnment of India in 2001-2002 and is discussed by India's former high commissioner to Pakistan, G. Parthasarathy, in "The Bush Administration-A H ouse Divided," Business L ine, August 30, 2002.

9. Although it is often believed that the Pashtun exaltation of nang (honor), izaat (respect), and imandari (righteousness), which lie at the core of Pashtunwali, the Pashtun code of life, are disproportionately responsible for the tribal willingness to offer melmestiya (hospitality) to Taliban and alQ aeda stragglers who request assistance, the reality is far more complex. In the traditional understanding of Pashtunwali, any stranger who offers his tribal host respect and requests his assistance is indeed granted hospitality to the point of refuge, irrespective of the visitor's past actions or moral standing. It is not certain, however, that this code of Pashtunwali al one accounts for the tribes' decisions to offer sanctuary to the defeated Taliban and al-Q aeda remnants in the immediate aftermath of $O$ peration Enduring Freedom. For one thing, the old Pashtunwali code has suffered considerable erosion over the past few decades. To complicate things further, the significant resources possessed especially by al-Q aeda refugees have resulted in many situations where weal thy aliens simply purchase asylum, thus resulting in the rise of a new industry of "hospitality for hire" in the FATA. Finally, if Pashtunwali and lucre do not by themsel ves suffice to buy protection, targeted assassinations invariably do: Pakistani military officers deployed in the border areas have pointed out in private conversations that some significant proportion of the "hospitality" offered by at least some FATA tribes to their al-Q aeda guests is owed simply to fear growing out of previous instances of targeted killings by terrorists of the tribals who reported on their presence. Between the Pashtun honor 
code and tribal elites who either profit from or are frightened by the presence of al-Q aeda, the FATA continues to offer a variety of armed militant groups sanctuary and protection.

10. For a superb history of the Pakistani military's decisions in regard to raising, supporting, and utilizing Islamist terrorist groups for geopolitical purposes, see Husain H aqqani, Pakistan: B etween M osque and M ilitary (Washington, D .C.: C arnegie Endowment for International Peace, 2005).

11. The painful history of Pakistani state involvement with domestic sectarian groups is usefully summarized in S. V. R. N asr, "Islam, the State, and the Rise of Sectarian M ilitancy in Pakistan," in C hristophe Jaffrel ot, ed., Pakistan: N ation, N ationalism and the State (L ahore: Vanguard, 2005), pp. 85-114.

12. C . Christine Fair, The M adrassah C hallenge: M ilitancy and Religious E ducation in Pakistan (Washington, D.C.: U nited States Institute of Peace Press, 2007), p. 2.

13. See "Sectarian Violence in Pakistan," South Asia Terrorism Portal, 2007, www.satp.org/ satporgtp/countries/pakistan/database/sect-killing.htm; and N asr, "Islam, the State, and the Rise of Sectarian M ilitancy in Pakistan," pp. 85-86.

14. Aarish Ullah Khan, The Terrorist Threat and the Policy Response in Pakistan, SIPRI Policy Paper no. 11 (Stockholm: Stockholm International Peace Research Institute, September 2005), pp. 31-32, 35-44, http://books.sipri.org/files/PP/SIPRIPP11.pdf.

15. "The State of Sectarianism in Pakistan," Asia Report no. 95 (Islamabad/B russels: International C risisG roup, April 18, 2005), p. i, www.crisisgroup.org//ibrary/documents/asia/south_asia/095_the state_of_sectarianism_in_pakistan.pdf.

16. See the excellent discussion in C. C hristine Fair, The $C$ ounterterror $C$ oalitions: $C$ ooperation with Pakistan and India (Santa M onica, Calif.: RAND, 2004), pp. 21-27, www.rand.org/pubs/ monographs/2004/RAND_M G 141.pdf.

17. For a useful and comprehensive survey of the various terrorist groups operating in Kashmir, see "Terrorist G roups: An O verview" and the other derivative links at South Asia Terrorism Portal, n.d., http://satp.org/satporgtp/countries/india/states/jandk/terrorist_outfits/index.html.

18. Fair, The Counterterror C oalitions, p. 25.

19. See the discussion in "India and Pakistan: Is Peace Real ThisT ime? A C onversation between Husain H aqqani and AshleyJ. Tellis" (Washington, D.C .: C arnegie Endowment for International Peace, 2004), www.carnegieendowment. org/files/India-Pakistan.pdf.

20. N ote that the data collated in F igure 1 most likely underestimate the incidence of Taliban violence because the data are based primarily on international, rather than local, reporting.

21. "Pakistan Sheltering Taliban, Says British Officer," G uardian, M ay 19, 2006.

22. The broad geographic confines of the southern, central, and northern fronts along the Afghanistan-Pakistan border, illustrated in Figure 2, are drawn from Jones, "Pakistan's D angerous Game," p. 20. The role of Karachi as a conduit for Taliban financing and logisticsactivity is discussed in D ougl as Farah, "Terrorist Responses to I mproved U.S. Financial D efenses" (testimony before the U.S. H ouse of Representatives, C ommittee on Financial Services, Subcommittee on O versight and Investigations, February 16, 2005). The author is grateful to several Afghan, NATO, and Indian diplomats, officials, and military officers for their willingness to discuss off the record the operational dimensions of Taliban resurgence. For a useful discussion of the various Taliban leadership councils, see "C ountering Afghanistan's Insurgency: No Q uick Fixes," Asia Report no. 123 (Kabul/Brussels: International C risis Group, November 2, 2006), pp. 9-11, www.crisisgroup.org/ library/documents/asia/south_asia/123_countering_afghanistans_insurgency.pdf. 
23. Rubin, "Saving Pakistan," pp. 69-71; D aniel M arkey, "A False C hoice in Pakistan," Foreign Affairs, vol. 86, no. 4 (July/August 2007), pp. 90-92.

24. See "President Bush Welcomes President M usharraf to C amp D avid."

25. Bruce Riedel, "AI Q aeda Strikes Back," Foreign Affairs, vol. 86, no. 3 (M ay/June 2007), pp. 24-40.

26. The many dimensions of the Pakistani effort are summarized in Fair, The C ounterterror C oalitions, pp. 27-42.

27. The aims, objectives, and character of O peration Al M izan are discussed in M ajor Fayyaz Hussain Shah, "Pakistan's Role in the G lobal War on Terror" (master'sthesis, C anadian Forces C ollege, n.d.), wps.cfc.forces.gc.ca/papers/csc/csc33/mds/shah.doc.

28. Akram Gizabi, "Bajaur: Tribe and C ustom C ontinue to Protect al-Q aeda," Terrorism Focus (Jamestown Foundation), vol. 3, no. 2 (January 18, 2006), pp. 2-3, www.jamestown.org/terrorism/ news/uploads/tf_003_002.pdf; see also, M ichael Scheuer, "Assessing the Six Year H unt for O sama bin Laden," Terrorism Focus, vol. 4, no. 30 (September 25, 2007), pp. 5-7, www.jamestown.org/ terrorism/news/uploads/tf_004_030.pdf.

29. For a devastating critique of Pakistan's incomplete war on terrorism, including its failure to transform its domestic environment, which breeds extremism, see "U nfulfilled Promises: Pakistan's Failure to Tackle Extremism," Asia Report no. 73 (Islamabad/Brussels: International C risis G roup, January 16, 2004), www.crisisgroup.org/library/documents/asia/south asia/073 unfulfil promises pakistan extr.pdf; and Stephen Philip C ohen, "W ith Allies Like This: Pakistan and the War on Terror," in Adam Garfinkle, ed., A Practical Guide to Winning the War on Terrorism (Stanford: Hoover Institution Press, Stanford U niversity, 2004), pp. 103-116.

30. K. Alan Kronstadt, "International Terrorism in South Asia," CRS Report for Congress no. RS21658 (Washington, D.C.: Congressional Research Service, November 3, 2003), fpc.state.gov/documents/organization/26047.pdf; and K. Alan Kronstadt and Bruce Vaughn, "Terrorism in South Asia," CRS Report for Congress no. RL 32259 (Washington, D.C .: C ongressional Research Service, August 31, 2005), fpc.state.gov/documents/organization/52750.pdf.

31. The logic, calculus, and risks associated with this strategy in the context of generalized security competition between India and Pakistan are detailed in Ashley J. Tellis, Strategic Stability in South Asia (Santa M onica, C alif.: RAN D, 1997), pp. 42-54.

32. Ashley J. Tellis, "Fragile Peace," Force, July 2005, pp. 7-9.

33. A useful discussion of Pakistani calculations vis-à-vis the Taliban can be found in Syed Saleem Shahzad, "Pakistan, the Taliban and D adullah," Pakistan Security Research U nit, B rief N umber 3, D epartment of Peace Studies, U niversity of Bradford, M arch 1, 2007, http://spaces.brad.ac.uk:8080/ download/attachments/748/Brief3final ised1.pdf, and Jones, "Pakistan's D angerous G ame," pp. 24-26.

34. This reality is sometimes not sufficiently appreciated in the U nited States as is evident, for example, in the discussion in Thomas R. Pickering, Carla Hills, and M orton Abramowitz, "The Answer in Pakistan," Washington Post, N ovember 13, 2007, which rather innocuously asserts:

Both the Pakistan People's Party under Benazir Bhutto and the Pakistan M uslim League under Nawaz Sharif are opposed to the jihadi movements. They have publicly committed themsel ves to combating not only al-Q aeda but al so the political and military leadership of the Tal iban living in Pakistan, a point on which M usharraf has been notably reluctant to act. 
The dalliances between even moderate Pakistani political parties and variousjihadi organizations and their sponsors historically ought to induce caution in accepting such statements at face value. Although it is to be hoped that the Pakistan People's Party and the Pakistan M uslim League, learning from the past, are now convinced of the dangers that even externally useful jihadi organizations pose to the Pakistani state, the parties' political weaknesses often result in an undesirable dependence on various Islamist political parties that support such organizations. Such dependence, in turn, prevents them from implementing those liberal ideals they may otherwise be committed to, and this often results in compromised performance, even when other factors such as Pakistan's national interests and the issue of control over the military and intelligence services are discounted for purposes of analysis.

35. The best account yet published of U.S. diplomacy during the crisis can be found in Polly Nayak and M ichael Krepon, US C risis M anagement in South Asia's Twin Peaks C risis, Report no. 57 (Washington, D.C.: Stimson C enter, 2006), www.stimson.org/pub.cfm?id=327.

36. D an Balz, Bob Woodward, and Jeff Himmelman, "Afghan C ampaign's Blueprint E merges," Washington Post, January 29, 2002.

37. Roger C ohen, "D r. Jekyll and M r. M usharraf," N ew York Times, November 8, 2007; and Arthur Keller, "C aution: Taliban C rossing," N ew York Times, N ovember 28, 2007.

38. Rubin, "Saving Afghanistan," pp. 58-59.

39. M ichael Abramowitz and Karen DeYoung, "Bush Seeks Increased Pakistani Cooperation: M usharraf Vows Fight against 'Talibanization'," Washington Post, September 23, 2006.

40. "M usharraf Vows to Fight Extremism," CNN.com/world, August 10, 2007, www.cnn.com/2007/W O RLD/asiapcf/08/12/pakistan.jirga/index.html; "M usharraf Says N ot All Tal iban Terrorists," D aily Times (Pakistan), August 13, 2007.

41. Ibid.

42. For a useful overview of the multiple considerations informing Pakistan's Afghanistan policy, see Barnett R. Rubin, Afghanistan's Uncertain Transition from Turmoil to N ormalcy (N ew York: C ouncil on Foreign Relations, 2006).

43. For more on the issues related to Pakhtunistan, see Feroz Ahmed, Ethnicity and Politics in Pakistan (Karachi: O xford U niversity Press, 1998).

44. For an excellent summary of the current problems facing the Pakistani military in the N orth West F rontier Province, see H assan Abbas, "Is the N W FP Slipping O ut of Pakistan's C ontrol?" Terrorism M onitor (Jamestown Foundation), vol. 5, no. 22 (November 26, 2007), pp. 9-12, www.jamestown.org/terrorism/news/uploads/T M_005_022.pdf.

45. Jones, "Pakistan's D angerous Game," pp. 18-26.

46. The issue of the ISID 's role in fomenting terrorism, including the extent of its autonomy, is reviewed in Eben Kaplan, "T he ISI and Terrorism: Behind the Accusations," Backgrounder, C ouncil on Foreign Relations, N ew York, O ctober 19, 2007, www.cfr.org/publication/11644/.

47. Hassan Abbas, "Increasing Talibanization in Pakistan's Seven Tribal Agencies," Terrorism M onitor, vol. 5, no. 18 (September 27, 2007), pp. 1-5, www.jamestown.org/terrorism/news/uploads/ TM_005_018.pdf.

48. C hristine Fair, "Pakistan L oses Swat to Local Taliban," Terrorism Focus, vol. 4, no. 37 (N ovember 13, 2007), pp. 3-4, www.jamestown.org/terrorism/news/uploads/tf_004_037.pdf.

49. G riff Witte, "Pakistan Seen Losing Fight against Taliban and Al-Q aeda," Washington Post, October 3, 2007. 
50. Abbas, "Increasing Talibanization in Pakistan's Seven Tribal Agencies," p. 1.

51. "Pakistan's Tribal Areas: Appeasing the M ilitants," Asia Report no. 125 (Islamabad/Brussel s: International C risis Group, D ecember 11, 2006), p. i, www.crisisgroup.org/library/documents/asia/ south_asia/125_pakistans_tribal_areas_appeasing_the_militants.pdf.

52. An excellent analysis of the phenomenon of suicide bombings in Afghanistan can be found in Suicide Attacks in Afghanistan (2001-2007) (Kabul: U nited N ations Assistance M ission to Afghanistan, September 1, 2007), www.unama-afg.org/docs/_U N -D ocs/ U N AM A\%20-\%20SU IC IDE \%20ATTAC KS\%20ST U D Y\%20-\%20SE PT\%209th\%202007.pdf.

53. "C ountering Afghanistan's Insurgency: No Q uick Fixes," pp. 5-8.

54. Tim Foxley, "The Taliban's Propaganda Activities: H ow Well Is the Afghan Insurgency C ommunicating and What Is It Saying?" SIPRI project paper. Stockholm International Peace Research Institute, June 2007, p. 1, www.sipri.org/contents/conflict/foxley_paper.pdf.

55. See "Bin Laden's Letter to M ullah M ohammed O mar," http://en.wikisource.org/wiki/ Bin_Laden\%27s_letter_to_M ullah_M ohammed_O mar.

56. The Taliban-al-Q aeda relationship is usefully discussed in Jones, "Pakistan's D angerous G ame," pp. 21-23; and in Riedel, "Al Q aeda Strikes Back," pp. 25-26.

57. For a devastating indictment of Pakistan's policies toward the Taliban that amplifies these themes, see "Pakistan's Tribal Areas: Appeasing the M ilitants."

58. Barnett R. Rubin and Abubakar Siddique, "Resolving the Pakistan-Afghanistan Stalemate," Special Report no. 176 (Washington, D.C.: U nited States Institute of Peace, O ctober 2006), p. 12, www.usip.org/pubs/special reports/sr176.pdf.

59. C hristine Fair, "C onfronting the Pakistan Problem," Internet interview with F rontline, O ctober 3, 2006, www.pbs.org/wgbh/pages/frontline/taliban/pakistan/fair.html.

60. For a useful discussion of the challenges, see Pervaiz I qbal $\mathrm{C}$ heema and $\mathrm{M}$ aqsudul $\mathrm{H}$ asan N uri, eds., Tribal Areas of Pakistan: C hallenges and R esponses (I slamabad: I slamabad Policy Research Institute/H anns Seidel Foundation, 2005).

61. Fair, "C onfronting the Pakistan Problem."

62. For an excellent overview of these problems, see M ariam Abou Zahab, "C hanging Patterns of Social and Political Life among the Tribal Pashtuns in Pakistan," IEP-CERI/IN ALC O, unpublished manuscript.

63. A good survey of Pakistan's SIG INT and C O M INT capabilities can be found in Desmond Ball, Signals Intelligence (SIGINT) in South Asia: India, Pakistan, Sri Lanka (C eylon), C anberra Papers on Strategy and D efence no. 117 (C anberra: Australian N ational University, Strategic and D efence Studies C entre, 1996), pp. 41-62.

64. Ramesh Vinayak, "Wireless Wars," Tactical Link Systems, 2000, www.tactical-link.com/ india pakistan.htm.

65. For more on terrorists' use of the Internet, see Abdul Hameed Bakier, "GIM F D evelops D efensive and O ffensive Software for J ihadi O perations," Terrorism M onitor, vol. 5, no. 18 (September 27, 2007), pp. 7-9, www.jamestown.org/terrorism/news/uploads/T M_005_018.pdf.

66. D ana Priest and Ann Scott Tyson, "Bin L aden Trail 'Stone C old'," Washington Post, September 10, 2006.

67. "FATA Fact Sheet," U nited States Agency for International D evelopment, September 2007, www.usaid.gov/our_work/cross-cutting_programs/transition_initiatives/country/pakistan/fact.html. 

2007.

68. Jane Perlez, "Aid to Pakistan in Tribal Areas Raises Concerns," N ew York Times, July 16,

69. H assan Abbas, "Transforming Pakistan's Frontier C orps," Terrorism M onitor, vol. 5, no. 6 (M arch 29, 2007), pp. 5-8, www.jamestown.org/terrorism/news/uploads/T M_005_006.pdf.

70. M oeed Yusuf and Anit M ukherjee, "C ounterinsurgency in Pakistan: Learning from India," AEI N ational Security Outlook, September 2007, www.aei.org/publications/pubID .26888/ pub_detail.asp.

71. Ibid., p. 2.

72. For an overview of the physiography of the FATA, see Fazle Karim Khan, A G eography of Pakistan: E nvironment, People and E conomy (Karachi: O xford U niversity Press, 1991), pp. 19-25.

73. For a useful survey of the challenges associated with military operations in mountainous terrain, including those pertaining to counterterrorism missions associated with Afghanistan, see M ajor M uhammad Asim M alik, "M ountain Warfare-The N eed for Specialized Training," M ilitary Review, vol. 84, no. 5 (September-O ctober 2004), pp. 94-102.

74. The author is grateful to several senior serving and recently retired Pakistani military officers who were deployed to the FAT A for sharing their insights in regard to contemporary counterterrorism operations in the tribal areas.

75. Rajat Pandit, "M ultiple C onflicts Bleed Pak Army," Times of India, O ctober 30, 2007.

76. See "Less than H alf of Pakistani Public Supports Attacking AI Q aeda, C racking D own on F undamentalists," World Public O pinion.org, O ctober 31, 2007, www.worldpublicopinion.org/pipa/ articles/home_page/424.php?lb=hmpgl\& pnt=424\&nid=\&id.

77. Richard Wike, "M usharraf's Support Shrinks, E ven as M ore Pakistanis Reject Terrorism . . . and the U.S.," Pew G lobal Attitudes Project, August 8, 2007, http://pewresearch.org/pubs/ 561/pakistan-terrorism.

78. "Pakistan's Tribal Areas: Appeasing the M ilitants," pp. 13-20.

79. Farhana Ali and M ohammad Shehzad, "Pakistan's Radical Red M osque Returns," Terrorism M onitor, vol. 5, no. 20 (0 ctober 25, 2007), pp. 3-6, www.jamestown.org/terrorism/news/ uploads/T M_005_020.pdf.

80. Jones, “Pakistan's D angerous G ame," p. 15.

81. "O ral Statement of G eneral James L. Jones, USM C , Supreme Allied C ommander, Europe, before the Senate Foreign Relations C ommittee," U.S. Senate Committee on Foreign Relations, September 21, 2006, www.senate.gov/ foreign/testimony/2006/J onesTestimony060921.pdf.

82. Christopher M . Blanchard, "Afghanistan: N arcotics and U.S. Policy," CRS Report for Congress no. RL 32686 (Washington, D.C.: C ongressional Research Service, June 19, 2007), Summary. A joint U nited Nations-World Bank study on poppy cultivation in Afghanistan succinctly summarized the magnitude and the nature of the problem when it declared:

The magnitude and importance of Afghanistan's opium economy are virtually unprecedented and unique in global experience - it has been roughly estimated as equivalent to $36 \%$ of licit (i.e. non-drug) G D P in 2004/05, or if drugs are al so included in the denominator, $27 \%$ of total drug-inclusive GDP. The sheer size and illicit nature of the opium economy mean that not surprisingly, it infiltrates and seriously affects Afghanistan's economy, state, society, and politics. It generates large amounts of effective demand in the economy, provides incomes and employment including in rural areas (even though most of the final "value" from Afghan opium accrues outside the country), and supports the balance of payments and indirectly 
(through C ustoms duties on drug-financed imports) government revenues. The opium economy by all accounts is a massive source of corruption and undermines public institutions especially in (but not limited to) the security and justice sectors. There are worrying signs of infiltration by the drug industry into higher levels of government and into the emergent politics of the country. Thus it is widely considered to be one of the greatest threats to statebuilding, reconstruction, and development in Afghanistan.

See D oris Buddenberg and W illiam A. Byrd, eds., Afghanistan's D rug Industry: Structure, F unctioning, D ynamics, and Implications for C ounter-N arcotics Policy (Washington, D .C .: U nited N ations O ffice on D rugs and C rime and the World Bank, 2007), p. 1.

83. For a very useful survey of the multiple challenges facing Afghanistan, see Ali A. Jalali, "The Future of Afghanistan," Parameters, vol. 36 (Spring 2006), pp. 4-19.

84. Haroun M ir, "The Benefits of N egotiating with M oderate Taliban Leaders," C entral Asia-C aucasus Analyst, vol. 9, no. 8 (April 18, 2007), pp. 3-5, www.cacianalyst.org/files/ 070418Analyst.pdf.

85. “C ountering Afghanistan's Insurgency: No Quick Fixes," p. 20.

86. Kirk Semple, "In Afghanistan, Anger in Parliament Grows as President D efies M ajority's Wishes," N ew York Times, September 26, 2007.

87. For an insightful discussion of PRTs, see Charlotte Watkins, "Provincial Reconstruction Teams (PRT s): An Analysis of Their C ontribution to Security in Afghanistan" (master'sthesis, Oxford Brookes U niversity, September 2003).

88. N ile G ardiner, "The N ATO Riga Summit: T ime for Backbone in the Alliance," WebM emo no. 1261, Heritage Foundation, Washington, D.C., N ovember 27, 2006, p. 2, www.heritage.org/ Research/E urope/upload/wm_1261.pdf.

89. John Ward Anderson, "N ATO C onflicted over Afghanistan," Washington Post, O ctober 21, 2007.

90. John G odges, "Afghanistan on the Edge," Rand Review, vol. 31, no. 2 (Summer 2007), pp. 14-21, www.rand.org/pubs/corporate pubs/2007/RAN D_CP22-2007-08.pdf.

91. D avid Rohde and D avid E. Sanger, "H ow a 'G ood War' in Afghanistan Went Bad," N ew York Times, August 12, 2007.

92. For a review of these problems, see Paul G al lis, "N ATO in Afghanistan: A Test of the TransatIantic Alliance," CRS Report for C ongressno. RL 33627 (Washington, D .C .: C ongressional Research Service, July 16, 2007).

93. The characteristics of "post-heroic" societies and their implications are innovatively explored in E dward N . L uttwak, "Toward Post-H eroic Warfare," Foreign Affairs, vol. 74, no. 3 (M ay/June 1995).

94. The long-term presence of military forces, for example, will be a critical ingredient that determines whether NATO's recent victories-for example, retaking the northern $\mathrm{H}$ elmand town of M usa Q ala from Taliban control-can be consolidated. Although the recovery of M usa Q ala was undoubtedly both an operational and a psychological victory for the Afghan N ational Army and NATO forces, the recapture of the town does not in any way imply the definitive defeat of the Taliban. In fact, an analysis of the M usa Q ala operation suggests that its Taliban occupiers simply retreated into the mountains as the N ATO assault gathered steam. If past practices are any indication, the Taliban fighters who merged back into the rural population after their retreat are likely to seep back into town and attempt to recontrol it after a decent interval. D efeating this strategy will require a long-term presence in the area of effective Afghan and N ATO forces, both of which are currently in short supply. 
95. This appears to be the fear currently enveloping U.S. policy makers, according to recent news reports; see Karen DeYoung, "U.S. N otes Limited Progress in Afghan War: Strategic Goals Unmet, White H ouse C oncludes," Washington Post, N ovember 25, 2007.

96. For a useful review of the multiple challenges, see Andrew Feickert, "U.S. and C oalition M ilitary O perations in Afghanistan: Issues for C ongress," C RS Report for Congress no. RL 33503 (Washington, D.C.: C ongressional Research Service, January 11, 2006).

97. R. Nicholas Burns, "Statement [before the Senate C ommittee on Foreign Relations] on U.S.Pakistan Relations," Washington, D.C ., July 25, 2007, www.state.gov/p/us/rm/2007/89418.htm.

98. Ibid.

99. See the excellent discussion in C raig C ohen and Derek C hollet, "W hen $\$ 10$ Billion Is $\mathrm{N}$ ot E nough: Rethinking U.S. Strategy Towards Pakistan," Washington Q uarterly, vol. 30, no. 2 (Spring 2007), pp. 7-19.

100. D avid E. Sanger and M ark M azzetti, "Pakistan Faces Warning by Bush to Act on Terror," N ew York Times, February 26, 2007.

101. Roxana T iron, "Pakistan Lobbies against Sanctions as the Senate Takes U p 9/11 Bill," The Hill, February 27, 2007.

102. G lenn Kessler, "C ongress Sets Limits on Aid to Pakistan," Washington Post, D ecember 20, 2007.

103. The most considered and thoughtful example of such an approach may be found in F rédéric G rare, "Rethinking Western Strategies toward Pakistan: An Action Agenda for the U nited States and Europe" (Washington, D.C.: C arnegie Endowment for International Peace, 2007), www.carnegieendowment.org/files/grare_pakistan_final.pdf.

104. For a public report based on fragmentary information about what is obviously classified military planning, see Seymour Hersh, "Watching the Warheads-T he Risks to Pakistan's N uclear Arsenal," N ew Yorker, N ovember 5, 2001, pp. 48-54.

105. See the discussion in D aveed G artenstein-Ross, "W hile Pakistan Burns," Weekly Standard, vol. 13, no. 7 (O ctober 29, 2007), www.weeklystandard.com/C ontent/Public/Articles/ 000/000/014/253vpget.asp.

106. For more on the notions of specific and diffuse reciprocity, see Robert 0 . Keohane, "Reciprocity in International Relations," International 0 rganization, vol. 40, no.1 (1986), pp. 1-27.

107. M arkey, "A False Choice in Pakistan," p. 102.

108. On the collusion with Pakistani border patrols, see David E. Sanger and D avid Rohde, "U.S. Pays Pakistan to Fight Terror, but Patrols E bb," N ew York Times, M ay 20, 2007.

109. Coll, G host Wars, pp. 63-66.

110. Eric Schmitt, M ark M azzetti, and C arlotta G all, “U.S. H opes to U se Pakistani Tribes against Al Q aeda," N ew York Times, N ovember 19, 2007.

111. See the pertinent discussion in Senator Jack Reed, "Trip Report: Pakistan, Afghanistan, and Iraq," Office of Senator Reed, Washington, D.C., O ctober 2006, http://reed.senate.gov/ documents/Trip\%20Reports/tripreport\%20oct06\%20final.pdf.

112. On the misuse of coalition support funds by Pakistan, see D avid Rohde, C arlotta G all, E ric Schmitt, and D avid E. Sanger, "U.S. Officials See Waste in Billions Sent to Pakistan," N ew York Times, December 24, 2007. 
113. Joshua Kurlantzick, "Time's Up: The U.S. N eeds to Abandon M usharraf Today," N ew Republic, N ovember 5, 2007.

114. This recommended course of action is based on the premise that President $M$ usharraf cannot simply be forced from office by the actions of outside powers, including the U nited States (even if Washington sought to pursue such a goal), and that the Pakistan Army will not abandon M usharraf short of a catastrophic meltdown of law and order in the country. G iven these realities - and the fact that democracy in Pakistan remains the best hope for the triumph of moderation- the U nited States ought to focus less on shaping political outcomes in the forthcoming election and more on assuring a responsive, credible, and legitimate electoral process. The civilian government produced by this election should then be supported as the instrument for conducting a reinvigorated battle against extremism and for renegotiating the political compact that will define the character of Pakistan's governing regime for the long term. A discussion of the most important innovations essential to Pakistan's stability over the secular period can be found in AshleyJ. Tellis, "U.S. Strategy: Assisting Pakistan's Transformation," Washington Q uarterly, vol. 28, no. 1 (Winter 2004-2005), pp. 97-116.

115. G odges, "Afghanistan on the Edge," pp. 14-21. 


\section{C arnegie E ndowment for International Peace}

The $\mathrm{C}$ arnegie Endowment for International Peace is a private, nonprofit organization dedicated to advancing cooperation between nations and promoting active international engagement by the U nited States. Founded in 1910, C arnegie is nonpartisan and dedicated to achieving practical results. Through research, publishing, convening and, on occasion, creating new institutions and international networks, Endowment associates shape fresh policy approaches. Their interests span geographic regions and the relations between governments, business, international organizations, and civil society, focusing on the economic, political, and technological forces driving global change.

Building on the succesfful establishment of the C arnegie M oscow Center, the Endowment has added operations in Beijing, Beirut, and Brussels to its existing offices in Washington and $\mathrm{M}$ oscow, pioneering the idea that a think tank whose mission is to contribute to gl obal security, stability, and prosperity requires a permanent international presence and a multinational outlook at the core of its operations.

The Endowment publishes Foreign Policy, one of the world's leading journals of international politics and economics, which reaches readers in more than 120 countries and in several languages. 


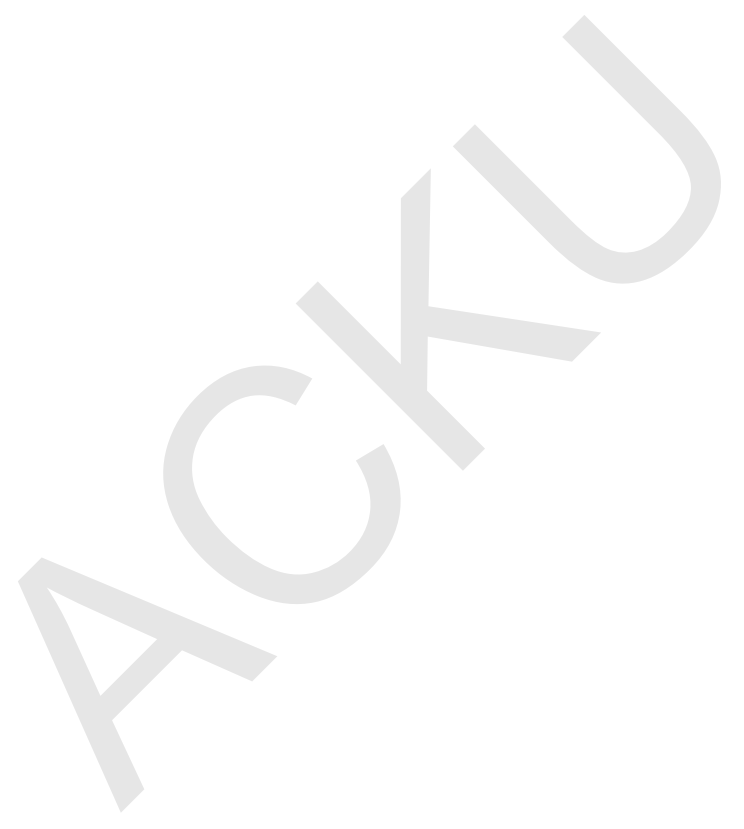




\section{CARNEGIE ENDOWMENT}

FOR INTERNATIONAL PEACE 